\title{
C 55.302:
}

R 24/8/ EAST PACIFIC

\section{Recovery Plan for U.S. Pacific Populations} of the

\section{East Pacific Green Turtle}

(Chelonia mydas)

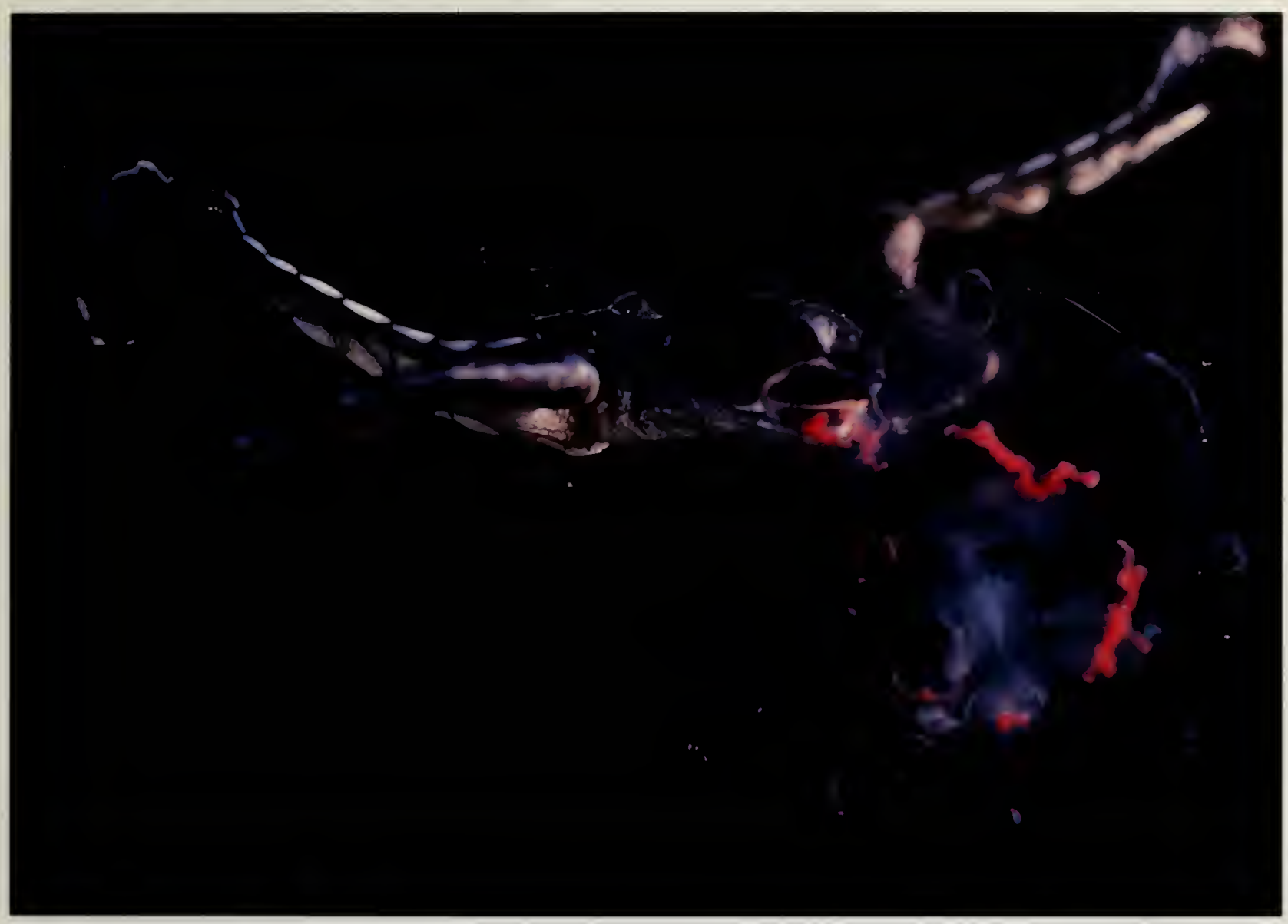

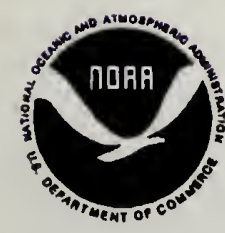

U.S. Department of Commerce

National Oceanic and Atmospheric Administration National Marine Fisheries Service

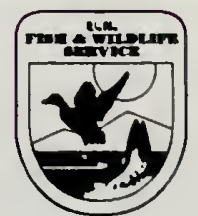

U.S. Department of the Interior U.S. Fish and Wildlife Service 
Cover Photograph Courtesy of Kim Cliffton 


\section{RECOVERY PLAN FOR U.S. PACIFIC POPULATIONS OF THE EAST PACIFIC GREEN TURTLE}

(Chelonia mydas)

\section{Prepared by the}

Pacific Sea Turtle Recovery Team

\section{JUN 171998}

for

National Marine Fisheries Service

Documents Collection

Silver Spring, Maryland

and

Pacific Region

U.S. Fish and Wildlife Service

Portland, Oregon

Approved:

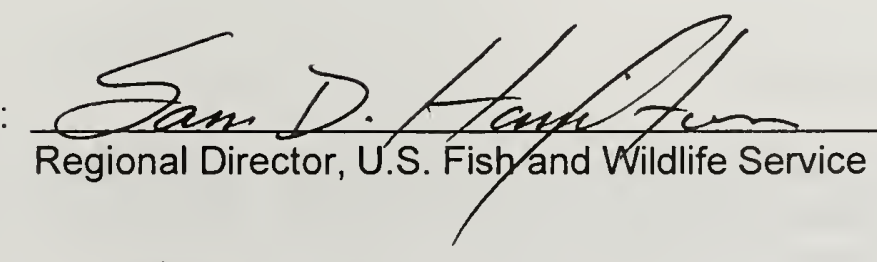

Date:

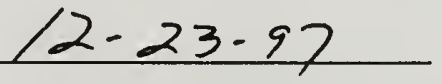

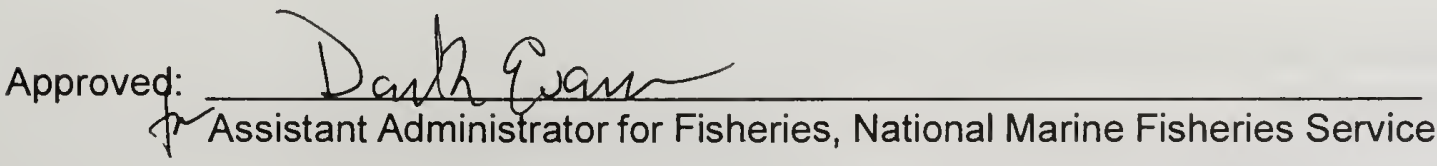

Date: $1 / 1298$ 
Recovery plans delineate reasonable actions which are believed to be required to recover and/or protect the species. Plans are prepared by the National Marine Fisheries Service (NMFS) and the U.S. Fish and Wildlife Service (FWS), and sometimes with the assistance of recovery teams, contractors, State agencies and others. Objectives will only be attained and funds expended contingently upon appropriations, priorities and other budgetary constraints. Recovery plans do not necessarily represent the views nor the official positions or approvals of any individuals or agencies, other than those of NMFS and the FWS which were involved in the plan formulation. They represent the official positions of NMFS and the FWS only after they have been approved by the Assistant Administrator for Fisheries or the Regional Director. Approved recovery plans are subject to modification as dictated by new findings, changes in species status and the completion of recovery tasks.

Literature citations should read as follows:

National Marine Fisheries Service and U.S. Fish and Wildlife Service. 1998. Recovery Plan for U.S. Pacific Populations of the East Pacific Green Turtle (Chelonia mydas). National Marine Fisheries Service, Silver Spring, MD.

Additional copies of this plan may be purchased from:

Fish and Wildlife Reference Service

5430 Grosvenor Lane

Suite 110

Bethesda, Maryland 20814

(301)492-6403 or

$1-800-582-3421$

The fee for the plan varies depending on the number of pages of the plan. 


\section{TABLE OF CONTENTS}

(East Pacific Green)

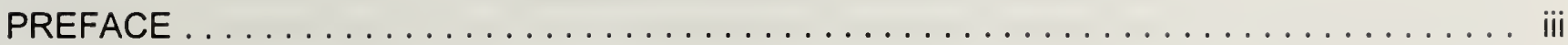

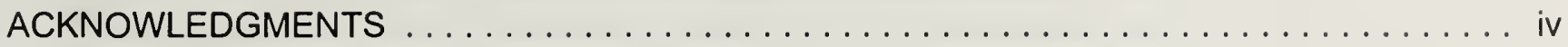

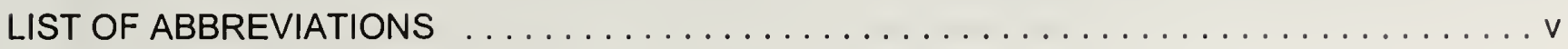

EXECUTIVE SUMMARY $\ldots \ldots \ldots \ldots \ldots \ldots \ldots \ldots \ldots \ldots \ldots \ldots \ldots \ldots \ldots \ldots \ldots$

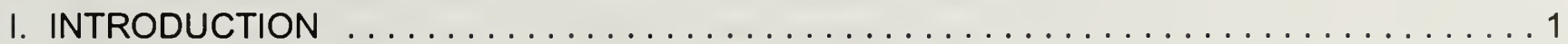

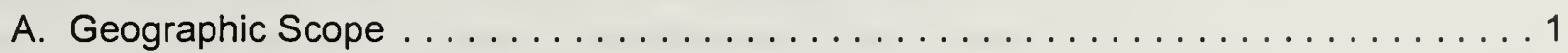

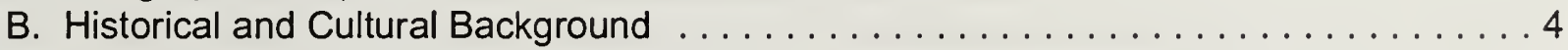

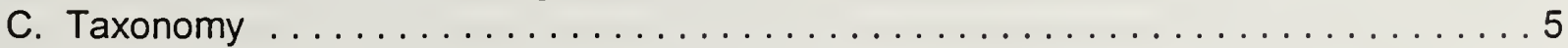

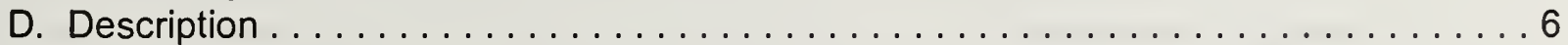

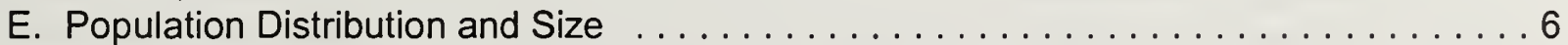

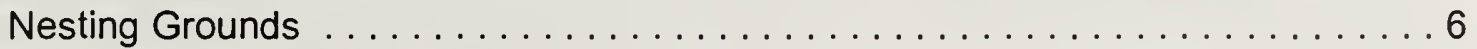

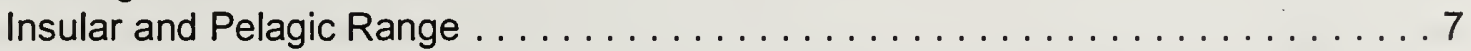

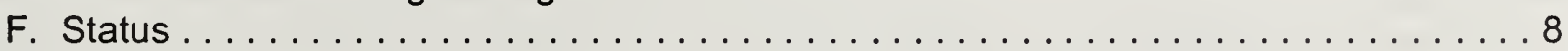

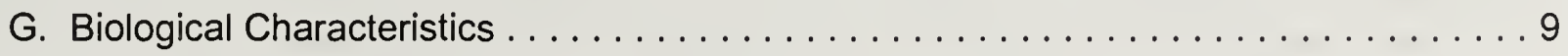

Migration and Movements $\ldots \ldots \ldots \ldots \ldots \ldots \ldots \ldots \ldots \ldots$

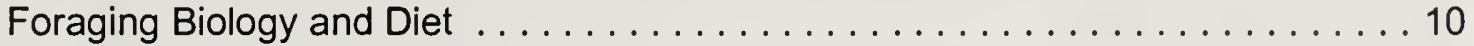

Growth ....................................... 10

Reproduction ................................ 11

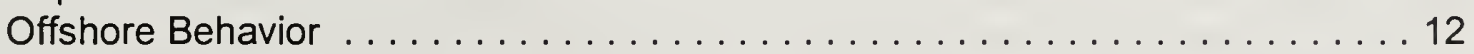

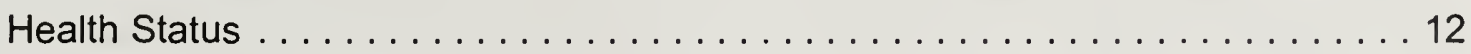

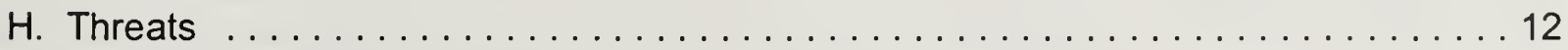

Pacific Synopsis . . . . . . . . . . . . . . . . . . . . . . . 13

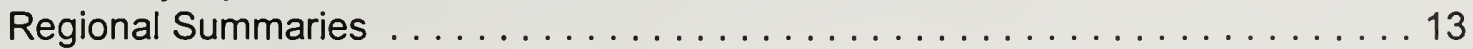

U.S. West Coast ........................... 13

Other U.S. Areas .............................. 13

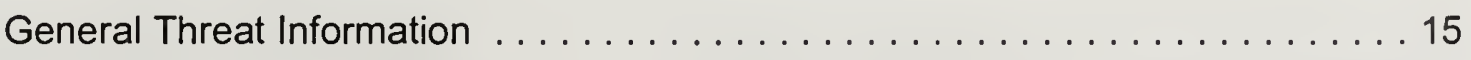

Nesting Environment ......................... 15

1. Directed Take .......................... 15

2. Increased Human Presence . . . . . . . . . . . . . . . . . . . 15

3. Coastal Construction .......................... 15

4. Nest Predation ... . . . . . . . . . . . . . . . . . . . . . . . 15

5. Beach Erosion . . . . . . . . . . . . . . . . . . . . . 16

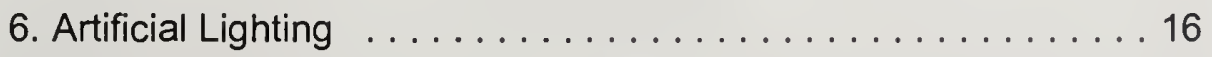

7. Beach Mining ...................... 16

8. Vehicular Driving on Beaches ................ 16

9. Exotic Vegetation . . . . . . . . . . . . . . . . . . . 16

10. Beach Cleaning .......................... 17

11. Beach Replenishment . . . . . . . . . . . . . . . . . . . 17

Marine Environment . . . . . . . . . . . . . . . . . . . 17

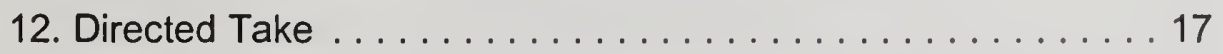


13. Natural Disasters . . . . . . . . . . . . . . . . . . . . . . 17

14. Disease and Parasites . . . . . . . . . . . . . . 17

15. Algae, Seagrass and Reef Degradation ............ 18

16. Environmental Contaminants ................. 18

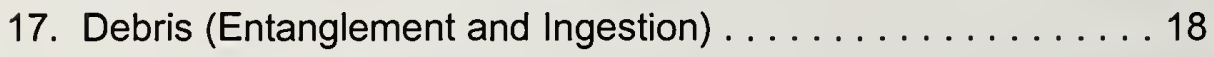

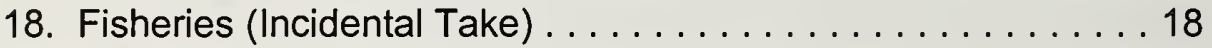

19. Predation ............................ 19

20. Boat Collisions ........................ 19

21. Marina and Dock Development ............... 19

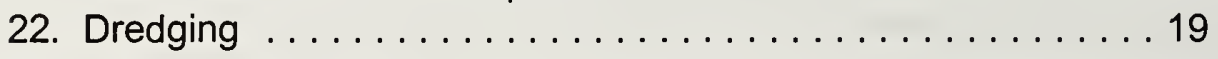

23. Dynamite "Fishing" ..................... 20

24. Oil Exploration and Development ................. 20

25. Power Plant Entrapment .................... 20

26. Construction Blasting . . . . . . . . . . . . . . . 20

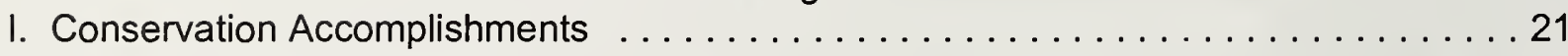

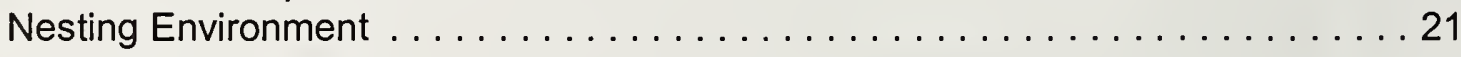

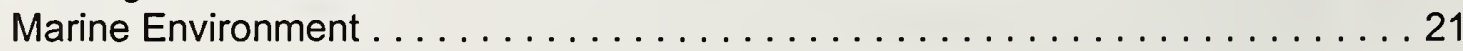

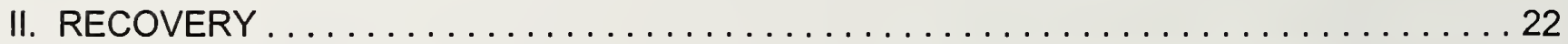

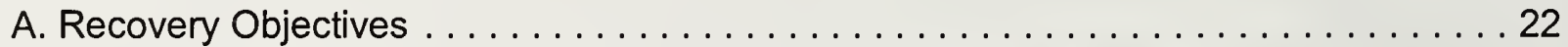

B. Step Down Outline and Narrative for Recovery ..................... 23

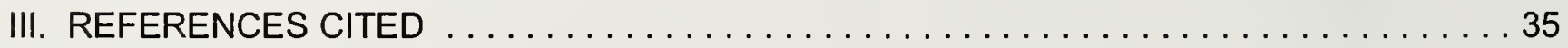

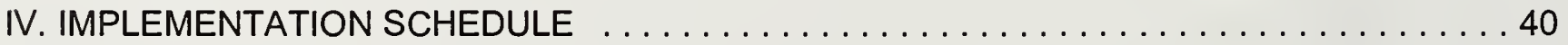




\section{PREFACE}

The National Marine Fisheries Service (NMFS) and the U.S. Fish and Wildlife Service (FWS) share responsibilities at the Federal level for the research, management, and recovery of Pacific marine turtle populations under U.S. jurisdiction. To accomplish the drafting of this recovery plan, NMFS appointed a team of professional biologists experienced with marine turtles in the Pacific region. This document is one of six recovery plans (one for each of the five species plus one for the regionally important population of the East Pacific green turtle).

While similar in format to previously drafted sea turtle recovery plans for the Atlantic, Caribbean, and Hawaii, the unique nature of the wider Pacific region required some modification of the recovery plan format. The geographic scope of the present plan is much larger than any previously attempted and considers areas from the western coastal United States extending to Guam. Furthermore, the amount of jurisdictional overlap between nations, commonwealths, territories and compact-of-free-association-states and their various turtle populations required a broader management perspective than has been attempted previously. Finally, sea turtles have not been studied as comprehensively in the Pacific as in other U.S. areas, and thus there are many areas in the Pacific where basic biological and ecological information must be obtained for management purposes. Thus, these plans have more extensive text on the general biology of the turtles, so that they might act as a resource to managers seeking a handy reference to the species. The plans are also subdivided into U.S. jurisdictional areas (i.e., the various territories and the commonwealth), so that local managers can address issues within their respective regions more easily.

Because of the previously noted aspects of marine turtle distribution in the Pacific (e.g., wide geographic range, multiple jurisdictions), the Recovery Team relied on the input and involvement of a large number of advisers, as can be noted by the lengthy Acknowledgments section. It is hoped that the resulting document is one that acts as a pragmatic guide to recovering the threatened and endangered sea turtle populations in the Pacific Ocean.

The members of the Pacific Sea Turtle Recovery Team and the authors of this document are:

Scott A. Eckert, Ph.D. (Team Leader)

Hubbs-Sea World Research Institute

Javier Alvarado, Ph.D.

Universidad de Michoacan, Mexico

George Balazs

National Marine Fisheries Service

Richard Byles, Ph.D.

U.S. Fish and Wildlife Service

Peter Craig, Ph.D.

Office of Wildlife and Marine Resources, Government of American Samoa

Peter Dutton, Ph.D.

Texas A\&M University
Karen Eckert, Ph.D.

Wider Caribbean Sea Turtle Conservation Network (WIDECAST)

John Engbring

U.S. Fish and Wildlife Service

James Maragos, Ph.D.

East-West Center

Robert Pitman

National Marine Fisheries Service

Susan Pultz

U.S. Fish and Wildlife Service

James I. Richardson, Ph.D.

University of Georgia 


\section{ACKNOWLEDGMENTS}

The team wishes to thank and acknowledge the following technical advisors and contributors to these recovery plans:

David Aldan, Department of Natural Resources, Saipan, MP

Pablo Arenas, Inter-American Tropical Tuna Commission

Representative Mariano W. Carlos, Palau

Chuck Cook, The Nature Conservancy

Donald David, FSM

Gerry Davis, Division of Aquatic and Wildlife Resources, Dept. Agriculture, Guam

Oscar DeBrum, former Chief Secretary, RMI

Adrienne Farago, SPREP/RMTCP, Western Samoa

Michael Guilbeaux, Georgia Sea Turtle Cooperative

Vincent Hachiglou, Marine Resources Management Division, Yap State Government

Heidi Hirsh, Andersen Air Force Base, Guam

Paul Holthus, IUCN Biodiversity Program

Luciana Honigman, The Nature Conservancy

Noah Idechong, Division of Marine Resources, Palau

John lou, Marine Resources Management Division, Yap State Government

Bruce Jensen, Pacific Magazine

Harry Kami, Hilo, Hawaii

Angela Kay Kepler, Athens, Georgia

Steve Kolinski, Marine Resources Management Division, Yap State Government

Colin Limpus, Queensland National Parks and Wildlife Service, Australia

Becky Madraisau, Micronesian Mariculture Demonstration Center, Republic of Palau

B. Renè Màrquez-M., P.N.I.T.M./INP, Mexico

Donna McDonald, Ocean Planet Research

Ken McDermond, U.S. Fish and Wildlife Service, Honolulu

Jeffery Miller, Queensland Department of Environment \& Heritage, Australia

Susan Miller, South Pacific Regional Environment Program (SPREP)

Karen Miller McClune, Hubbs-Sea World Research Institute

Moses Nelson, Marine Resources Division, FSM

Peter Oliver, RMI

Arnold Palacios, Division of Fish and Wildlife, Dept. of Natural Resources, CNMI

Peter Pritchard, Florida Audubon Society

Georgita Ruiz, Colonia Irrigacion, Mexico

Laura Sarti, Universidad Naçional Autonoma de Mexico, Mexico

Fumihiko Sato, Ogasawara Marine Center, Japan

Katsufumi Sato, Kyoto University, Japan

Asterio Takesy, Secretary of Resources and Development, FSM

Natasha Tuato'o-Bartley, Department of Marine and Wildlife Resources, American Samoa

Itaru Uchida, Port of Nagoya Public Aquarium, Japan

Richard Wass, U.S. Fish and Wildlife Service

Phil Williams, National Marine Fisheries Service 


\section{LIST OF ABBREVIATIONS}

$\mathrm{CCL}$

CITES

CNMI

COE

DAWR

EEZ

ENSO

EPA

ESA

ETP

FENA

FSM

FWS

HSWRI

IATTC

INP

IUCN

$\mathrm{MHI}$

MIMRA

MMDC

MRMD

mtDNA

NMFS

NOAA

NPS

NRCS

NWHI

PNG

RMI

SCL

SDG\&E

SPREP

TAMU

TED

UNAM

USCG

USVI

WIDECAST curved carapace length

Convention on International Trade in Endangered Species of Wild Fauna and Flora

Commonwealth of the Northern Mariana Islands

U.S. Army Corps of Engineers

Division of Aquatic and Wildlife Resources

Exclusive Economic Zone

El Niño - Southern Oscillation

U.S. Environmental Protection Agency

Endangered Species Act

Eastern Tropical Pacific

females estimated to nest annually

Federated States of Micronesia

U.S. Fish and Wildlife Service

Hubbs-Sea World Research Institute

Inter-American Tropical Tuna Commission

Instituto Nacional de Pesca

International Union for the Conservation of Nature

Main Hawaiian Islands

Marshall Islands Marine Resource Authority

Micronesian Mariculture Demonstration Center

Marine Resources Management Division, Yap State government

mitochondrial DNA

National Marine Fisheries Service

National Oceanographic and Atmospheric Administration

National Park Service

Natural Resources Conservation Service (Soil Conservation Service)

Northwest Hawaiian Islands

Papua New Guinea

Republic of the Marshall Islands

straight carapace length

San Diego Gas \& Electric

South Pacific Regional Environment Program

Texas A \& M University

Turtle Excluder Device

Universidad Naçional Autonoma de Mexico

U.S. Coast Guard

U.S. Virgin Islands

Wider Caribbean Sea Turtle Conservation Network 


\section{EXECUTIVE SUMMARY}

Current Status: The East Pacific green turtle is listed as Endangered throughout its range. This regionally important population of the green turtle (Chelonia mydas although see Taxonomy), has exhibited an extreme decline over the last 30 years. This decline was undoubtably caused by the massive overharvest of wintering turtles in the Sea of Cortez between 1950 and 1970, and the intense collection of eggs between 1960 and early 1980 on mainland beaches of Mexico. Primary threats to the species in U.S. waters are from entanglement in debris and boat collisions. Primary threats in Mexico are the (illegal) harvest of turtles and eggs.

Goal: The recovery goal is to delist this regionally important population.

Recovery Criteria: To consider de-listing, all of the following criteria must be met:

1) All regional stocks that use U.S. waters have been identified to source beaches based on reasonable geographic parameters.

2) Each stock must average 5,000 (or a biologically reasonable estimate based on the goal of maintaining a stable population in perpetuity) females estimated to nest annually (FENA) over six years.

3) Nesting populations at "source beaches" are either stable or increasing over a 25-year monitoring period.

4) Existing foraging areas are maintained as healthy environments.

5) Foraging populations are exhibiting statistically significant increases at several key foraging grounds within each stock region.

6) All priority \#1 tasks have been implemented.

7) A management plan to maintain sustained populations of turtles is in place.

8) International agreements are in place to protect shared stocks.

Actions Needed: Six major actions are needed to achieve recovery (not in order of priority):

1) Minimize boat collision mortalities, particularly within San Diego County, California.

2) Minimize incidental mortalities of turtles by commercial fishing operations.

3) Support the efforts of Mexico and the countries of Central America to census and protect nesting East Pacific green turtles, their eggs and nesting beaches.

4) Determine population size and status in U.S. waters through regular surveys.

5) Identify stock home range(s) using DNA analysis.

6) Identify and protect primary foraging areas in U.S. jurisdiction. 


\title{
RECOVERY PLAN FOR U.S. PACIFIC POPULATIONS OF THE EAST PACIFIC GREEN TURTLE (Chelonia mydas)
}

\author{
Prepared by the \\ U.S. Pacific Sea Turtle Recovery Team
}

\section{INTRODUCTION}

\section{A. Geographic Scope}

Defining the geographic range of a population of sea turtles in the Pacific Ocean is difficult. Sea turtles are highly migratory, and the life histories of all species exhibit complex movements and migrations through geographically disparate habitats. Because the U.S. Pacific Sea Turtle Recovery Team is required to focus on sea turtle populations that reside within U.S. jurisdiction, we must delineate what constitutes a population where individuals reside permanently or temporarily within U.S. jurisdiction and what actions must be taken to restore that population. This has proven to be quite challenging because sea turtles do not recognize arbitrary national boundaries and in most cases we have only limited data on stock ranges and movements of the various populations. In this recovery plan we have tried to make these judgements with the best information available, and to suggest means by which the United States can promote population recovery.

Geographic scope (from a U.S. jurisdictional perspective) for all six of the U.S. Pacific sea turtle recovery plans (written for five species and one regionally important population) is defined as follows: in the eastern Pacific, the west coast of the continental United States (Figure 1a); in the central Pacific, the state of Hawaii and the unincorporated U.S. territories of Howland, Baker, Wake, Jarvis, and Midway Islands, Johnston Atoll, Palmyra Atoll, and Kingman Reef; in Oceania, Guam, the Commonwealth of the Northern Mariana Islands (CNMI), and American Samoa (see Figure $1 \mathrm{~b}$ ). The U.S.-affiliated but independent nations of the Republic of the Marshall Islands (RMI), Federated States of Micronesia (FSM), and the Republic of Palau are also included. The FSM includes the states of Yap, Pohnpei, Chuuk, and Kosrae. While independent, all retain clearly defined administrative links to the United States in the areas of defense, natural resource management, and some regulatory issues. Thus, we include them here in an advisory capacity. Finally, where eastern Pacific sea turtles are held in common with Mexico, discussion of the status and recovery of these stocks will also include discussion of the resource under Mexican jurisdiction. In all cases where U.S. sea turtle stocks are held in common with other sovereign states, we have tried to suggest means by which the United States can support efforts at management of those stocks by those states. We recognize that other nations may have different priorities than the United States and we have sincerely attempted to avoid establishing policy for those nations.

Because of the highly migratory behavior of adult turtles, and the likelihood of shifting habitat requirements of post-hatchlings and juveniles, the populations of East Pacific green turtles, Chelonia mydas, in the Pacific Ocean cross international boundaries. 


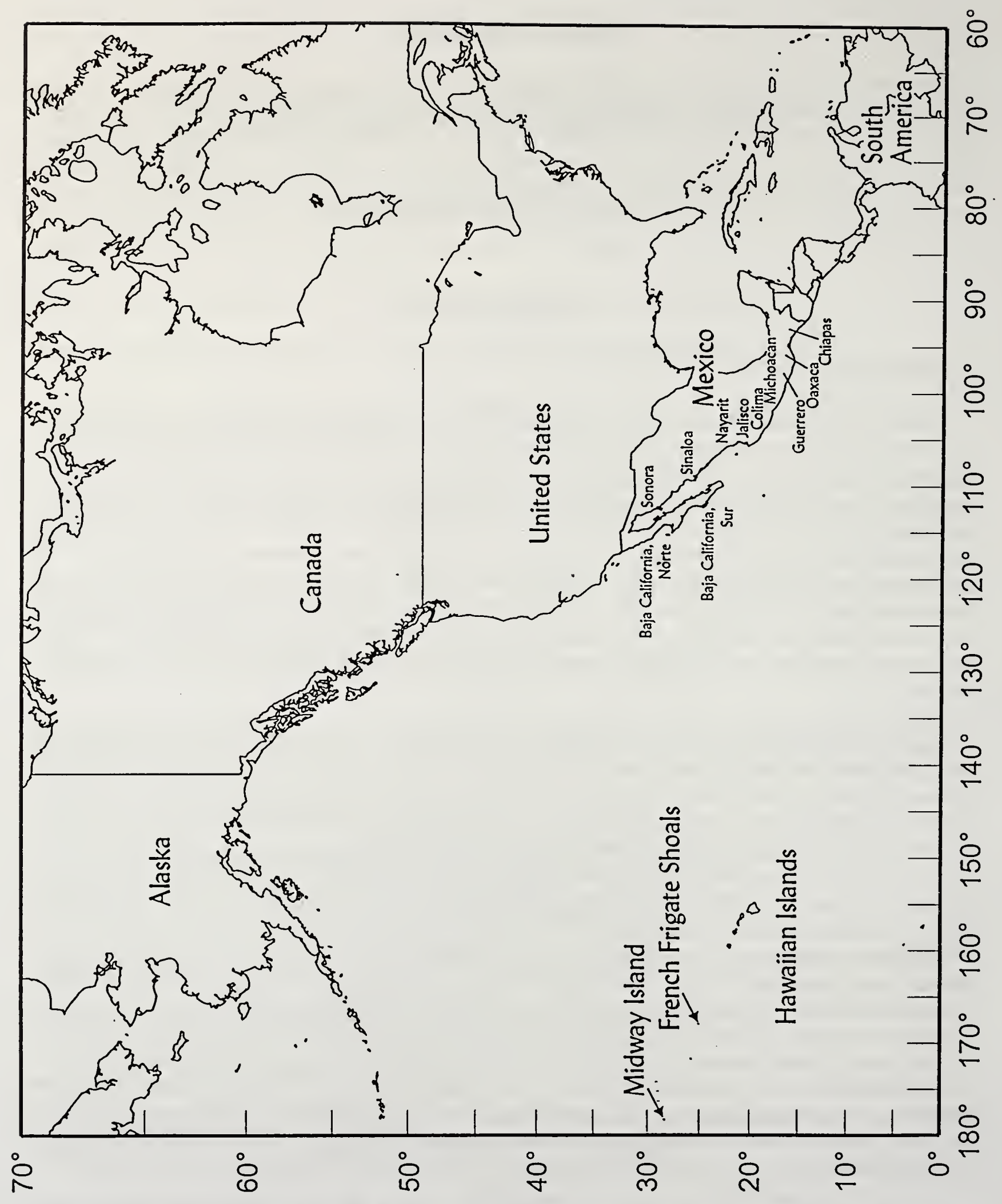

Figure 1a. Western coasts of the United States, Canada and Mexico (as well as Central and northern South America) constitute a shared habitat for Pacific sea turtles. 


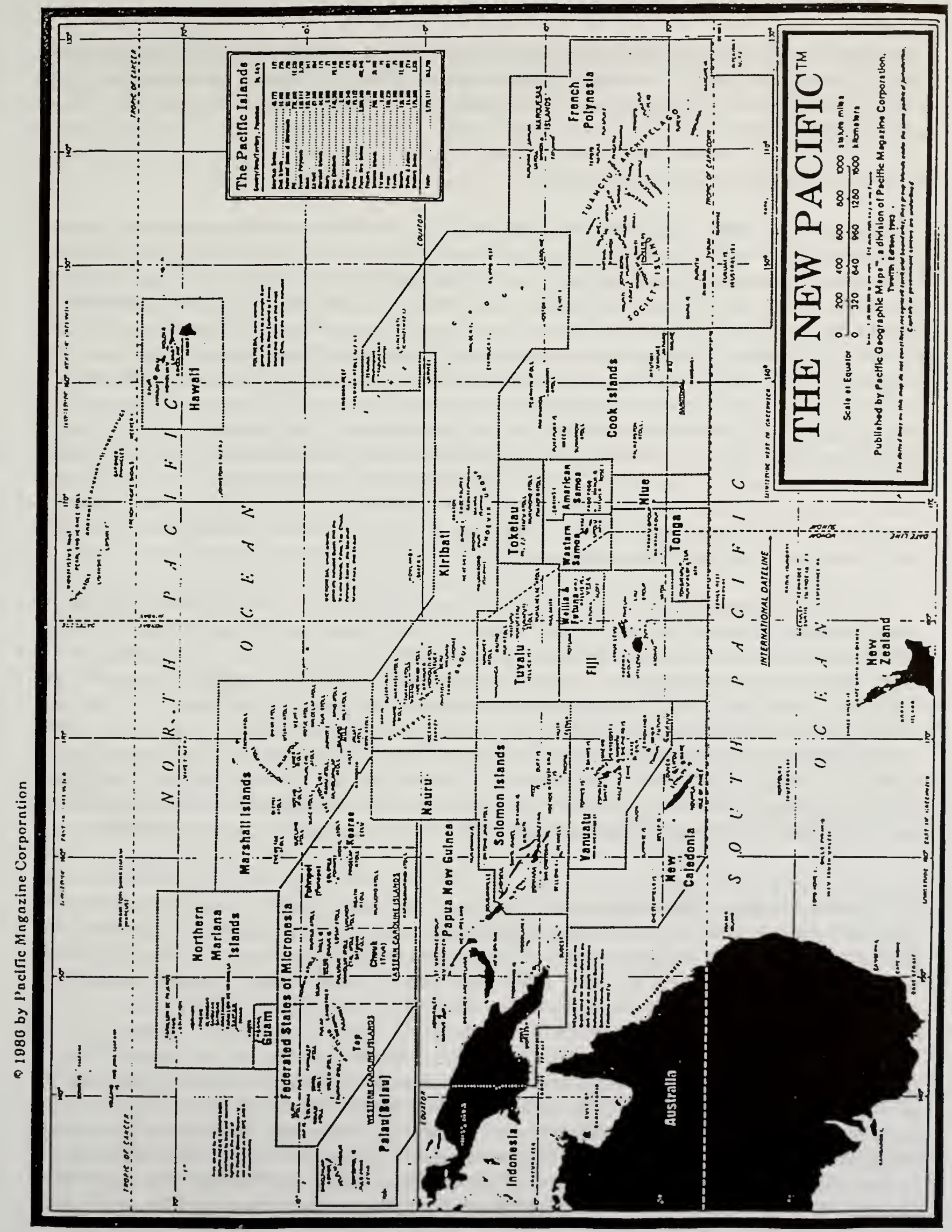

Figure 1b. The western Pacific constitutes a shared habitat for Pacific sea turtles. 
The west coasts of Central America, Mexico and the United States constitute a shared habitat for East Pacific green turtles. The following discussions acknowledge the extended range of East Pacific green turtles by incorporating relevant biological information from within and without U.S. political jurisdiction.

\section{B. Historical and Cultural Background}

Prior to commercial exploitation, the East Pacific green turtle was abundant in the eastern Pacific from Baja California south to Peru and west to the Galapagos Islands. Historically the species was plentiful in the feeding grounds within the Gulf of California (Sea of Cortez) and along the Pacific coast of Baja California (Cliffton et al. 1982). An indication of its former numbers is found in the report of the visit of the vessel Albatross to Tortugas Bay on the Pacific coast of Baja California (Mexico) in April 1889, when a catch of 162 turtles was made in a single haul by a 200 $m$ seine (Parsons 1962). As late as the 1960 s the East Pacific green turtle was still abundant in its major nesting grounds in North America; that is the beaches of Colola and Maruata Bay, Michoacán, Mexico. It is estimated that in the late 1960s, $500-1,000$ females nested nightly in Colola during peak season. Cliffton et al. (1982) extrapolated that perhaps 25,000 females nested annually in Michoacán at that time. Earlier observations tend to corroborate this figure; Peters (1956) reported tracks of some 250 turtles on a $0.8 \mathrm{~km}$ stretch of beach at Maruata Bay in August 1950, two months before peak nesting. Cliffton et al. (1982) estimated that approximately 900 turtles must have nested at Maruata Bay within several days of Peters' observations.

The East Pacific green turtle has been used by coastal indigenous communities throughout its range since pre-Columbian times. The Seri Indians of the Sonora coast in Mexico harvested East Pacific green turtles in the Gulf of California, and turtle meat represented the main component in their diet at least until the end of the 1800s (Caldwell 1963). The Seri also utilized turtle shells for housing material, and flipper integument was employed as footwear. In Oaxaca, Mexico, the Huave Indians traditionally consumed the meat of East Pacific green turtle adults and juveniles (Márquez 1990). For the Nahuatl Indians of the Michoacán coast East Pacific green turtle eggs were an important dietary staple (Alvarado and Figueroa 1991a). However, with the introduction of commercial demand for sea turtle products, the centuries old, low-impact, traditional subsistence use of the East Pacific green turtle was replaced by a rapidly expanding commercial fishery.

In the northern Mexican feeding grounds East Pacific green turtles were first heavily fished at the turn of the century, when an estimated 1,000 East Pacific green turtles per month were shipped from the Pacific side of Baja California (Magdalena Bay, Scammon's Lagoon, Tortugas Bay) and Gulf of California (Bahia de los Angeles) to San Diego and San Francisco in California, United States (O'Donnell 1974 in Cliffton et al. 1982). By the 1930's, the market for sea turtle meat had decreased in the United States, while in Mexico - especially in the border towns of Tijuana, Mexicali and Nogales, and the major cities in Baja California and Sonora - the demand for turtle meat grew steadily. From 1956 to 1963, East Pacific green turtles harvested in the northern Mexican feeding grounds were the most important component of the Mexican turtle fishery, with a total live weight production of 3,430 metric tons (Groombridge and Luxmoore 1989). In the early 1970s large numbers of overwintering East Pacific green turtles were discovered near Tiburon Island in the Gulf of California. The torpid turtles were lying motionless at depths of 10-30m (Felger et al. 1976). Intensive hunting of the easily caught overwintering turtles began in 1975, when five boats were landing 4-5 metric tons of turtles per week from late November to early March (Cliffton et al. 1982). 
Overwintering sites were successively decimated and the East Pacific green turtle was "virtually extirpated" from the Gulf of California by the late 1970s (Cliffton et al. 1982). According to Cliffton (in litt. to J. Woody, 5 May 1991) who conducted a 30-day exploration of the Midriff Islands region in the summer of 1990, adult East Pacific green turtles were extremely scarce. Cliffton quotes native informants as stating that most of the East Pacific green turtles remaining in the Upper Gulf of California are juveniles weighing an average of about $20 \mathrm{~kg}$.

Commercial exploitation of East Pacific green turtles in the nesting area in Michoacán was initiated considerably later than in the northern feeding grounds. Prior to the 1950 s the coastal breeding sites were relatively undisturbed as the coastline was virtually uninhabited and inaccessible. During the 1950 s coastal areas were increasingly cleared and the coastal settlements of Maruata and Colola were established. Access to the area remained difficult by land and, at that time, use of turtles by the local Nahuatl Indians was at a subsistence level. During the 1960 s commercial markets for sea turtle products, including both leather and eggs, were developed. In the early 1970 s approximately 70,000 eggs were collected each night during the breeding season at Colola and an additional 10,000 - 20,000 from Maruata Bay (Cliffton et al. 1982). This nearly $100 \%$ harvest of eggs continued until 1980 when armed protection of Colola and Maruata was begun and hatcheries for the relocation of nests were established (Alvarado et al. 1985).

Sea turtle leather processing in Mexico had been on a local, artisanal level up until the end of 1963 (Groombridge and Luxmoore 1989). During 1964, with the increase in international demand for the product, larger scale, industrial processing began (Alvarado and Figueroa 1989). From the mid-1960s to mid-1970s East Pacific green turtles in Michoacán were harvested mainly for their skins. During the mid-1970s breeding seasons, local fishermen were capturing $40-80$ turtles per day in Maruata, or about 7,000-15,000 turtles per season. Turtles were captured with shark gillnets in front of the nesting beaches and stripped of their hides (Cliffton et al. 1982). From 1965 to 1977 more than 165,000 East Pacific green turtles were harvested in the Mexican Pacific (Groombridge and Luxmoore 1989). In 1978 a new coastal highway reached the area, providing smugglers from the northern states of Sinaloa and Sonora easy access to the Michoacán turtles. Since then most poached turtles from this area have been smuggled to northern Mexico for meat consumption (Alvarado and Figueroa 1990). This fishery has been by far the most important factor in the collapse of East Pacific green turtle populations.

There are no accurate quantitative records of historical abundance of East Pacific green turtles in the Galapagos Islands, the only significant nesting area outside of Mexico. Only local inhabitants are legally allowed to fish for turtles and only on a subsistence basis; egg poaching is practically nonexistent (Green and Ortiz-Crespo 1982).

\section{Taxonomy}

The generic name Chelonia was introduced by Brongniart (1800). The specific name mydas was first used by Linnaeus (1758). The genus Chelonia is often considered to include the single species C. mydas with two distinct subspecies recognized: the East Pacific green turtle C. $m$. agassizii (Bocourt 1868) in the eastern Pacific (from Baja California south to Peru and west to the Galapagos Islands) and the green turtle C. m. mydas (Linnaeus 1758) in the rest of the global range (Groombridge and Luxmoore 1989). Nevertheless, there has been some controversy over 
the taxonomic status of the East Pacific green turtle. The nesting populations of the east Pacific differ from other forms of mydas in size, coloration, carapace shape (Cornelius 1986; Groombridge and Luxmoore 1989), as well as in osteological features (Kamezaki and Matsui 1995). Nuclear DNA analysis of Chelonia populations showed that samples from the Pacific coast of Mexico and the Galapagos Islands were closely associated and fairly remote from other populations (Karl et al. 1992), however, mitochondrial DNA (mtDNA) analyses of the global C. mydas complex do not support the genetic distinctness of the East Pacific green turtle from Chelonia populations in other regions of the world (Bowen et al. 1992; Dutton et al. 1996). It is clear that the question of species status must ultimately be resolved by taking into account morphometric, genetic and behavioral aspects. In the absence of a thorough study of the morphology and genetics of the agassizii form, set in the context of the overall systematics of the C. mydas group, the East Pacific green turtle is considered to be a melanistic form of Chelonia mydas of the monotypic genus Chelonia for the purpose of this recovery plan.

Regardless of taxonomic designation ultimately conferred upon the melanistic form, the remaining large nesting populations of Chelonia in the east Pacific should be managed as distinct population units. This document presents an agenda for the recovery of these regionally distinct and important populations.

\section{Description}

The East Pacific green turtle is distinguished from the green turtle mainly by size, coloration and carapace shape. The carapace of the adult East Pacific green turtle is narrower, more strongly vaulted and more indented over the rear flippers than that of the green turtle (Cornelius 1986; Márquez 1990). The East Pacific green turtle is also conspicuously smaller and lighter than the green turtle. In the rookeries of Michoacán, Mexico, the mean size for nesting females is $82.0 \mathrm{~cm}$ in curved carapace length (CCL) (range 60.0-102, $n=718$ ) (Alvarado and Figueroa 1990). On the Galapagos Islands, the mean CCL for nesting females is $80.0 \mathrm{~cm}$ (range 74.0-100) (Márquez 1990). The mean straight carapace length (SCL) of nesting females at Playa Naranjo, Costa Rica is $82.9 \mathrm{~cm}$ (range 73.0-97.0, $\mathrm{n}=73$ ) (Cornelius 1976). Adult females weigh between $65-125 \mathrm{kgs}$ (Cornelius 1986). Adult males in the rookeries of Mexico are smaller than females with an average $\mathrm{CCL}$ of $77.0 \mathrm{~cm}$ (range 71.0-85.0, $\mathrm{n}=32$ ) (Figueroa 1989). Mean hatchling length in Michoacán is $4.5 \mathrm{~cm}$ in SCL (range 4.2-5.0, $\mathrm{n}=140$ ) (Zamora 1990).

In adult East Pacific green turtles, the carapace and dorsal surfaces of the head and flippers are olive-green to dark gray or black, while the plastron varies from whitish-grey to bluish or olive-grey. Considerable gray pigment often infuses the plastron. Hatchlings are black to dark grey above and white below with a white border around the dorsal edge of the carapace and flippers. Young juveniles are usually brightly colored with a mottled or radiating carapacial pattern of light and dark brown, reddish brown, olive and yellow (Caldwell 1962).

\section{E. Population Distribution and Size}

\section{Nesting Grounds}

There is no known nesting by this species in the United States or in any territory under U.S. jurisdiction. The main nesting sites for the East Pacific green turtle are located in the state of 
Michoacán, Mexico (Colola and Maruata beaches) and in the Galapagos Islands, Ecuador. The Michoacán rookeries support about one third of the East Pacific green turtle population (Cliffton et al. 1982). There are also less important nesting grounds in Mexico (Guerrero, Jalisco, Oaxaca, Chiapas, the islands of Clarion and Socorro) (Márquez 1990) and along the Central American Pacific coastline (Cornelius 1982). Between 1982 and 1989 the estimated East Pacific green turtle nesting population in Michoacán (Mexico) ranged from a high of 5,585 females in 1982 to a low of 940 in 1984 (Alvarado and Figueroa 1990). In October 1976 at least 13 females visited Clarion Island in the Revillagigedo archipelago in Mexico (Awbrey et al. 1984).

At Playa Naranjo, Costa Rica, Cornelius (1976) tagged 80 nesting East Pacific green turtles during 11 September 1971 - 31 March 1972 and estimated the population of nesting females to be between 125 and 175. In the Galapagos Islands an annual average of 1,400 nesting East Pacific green female turtles was registered between 1976 - 1982 (Hurtado 1984). Green (1994) reported that between 1975 and 1980, a total of 6,722 green turtles (including 611 males) was tagged at the nesting beaches and feeding grounds of the Galapagos Islands. There is scant information on numbers of nesting females at other nesting sites.

\section{$\underline{\text { Insular and Pelagic Range }}$}

The East Pacific green is the second-most sighted turtle in the east Pacific during tuna fishing cruises; they are frequent along a North-South band from $15^{\circ} \mathrm{N}$ to $5^{\circ} \mathrm{S}$ along $90^{\circ} \mathrm{W}$, and between the Galapagos Islands and Central American coast (Inter-American Tropical Tuna Commission, IATTC, unpubl. data). Along the Pacific coast of America, East Pacific green turtles have been reported as far north as British Columbia $\left(48.15^{\circ} \mathrm{N}\right)$ (Carl 1955 in Márquez 1990). Loshbaugh (1993) reported a "green turtle" stranding in Homer, Alaska, although it was not known whether the turtle originated from the nesting beaches of Mexico or Hawaii. Adult and juvenile green/East Pacific green turtles have also been reported either from gillnets or from beach strandings as far north as $47^{\circ}$ latitude along the Washington coastline (Eckert 1993).

Stinson (1984) reviewed sea turtle sighting records from northern Baja California to Alaska and determined that the East Pacific green turtle was the most commonly observed hard-shelled sea turtle on the U.S. Pacific coast. Most of the sightings $(62.0 \%)$ were reported from northern Baja California and southern California. The northernmost reported resident population of East Pacific green turtles occurs in San Diego Bay, California, where a small population (about 30) of mature and immature turtles concentrate in the warm water effluent discharged by the San Diego Gas and Electric Company power plant (Stinson 1984; Dutton and McDonald 1990a,b, 1992; McDonald et al. 1995). Based on morphology and preliminary genetic analysis, these turtles appear to have originated from nesting beaches in the east Pacific (Dutton et al. 1994); there is no known sea turtle nesting on the west coast of the United States.

Beyond sightings offshore of the western coast of the continental United States, there are no reported encounters with East Pacific green turtles in Hawaii or any territories or pelagic waters under U.S. jurisdiction (see Geographic Scope).

Sighting and stranding reports of "green" turtles along the west coast of the United States are probably mostly of the East Pacific green. It is not known whether they regularly migrate from breeding grounds in Mexico to specific areas along the North American coast, or whether these 
turtles are vagrants that occasionally stray into more northern waters, perhaps moving with "EI Niño" currents. Recently (October 9, 1996), a live, cold-stunned East Pacific green turtle was recovered from Prince William Sound, Alaska (S. Eckert, pers. comm.)

South of the United States, East Pacific green turtles are widely distributed in the coastal waters of Mexico and Central America (e.g., Cliffton et al. 1982; Cornelius 1982, 1986; Alvarado and Figueroa 1990). Along the coast of Mexico and Central America the main aggregations of East Pacific green turtles occur in the breeding grounds of Michoacán, Mexico (August-January) and year-round in the feeding areas such as those located on the west coast of Baja California, in the Gulf of California (Sea of Cortez) and along the coast of Oaxaca. Foraging is also reported from Central America, especially in El Salvador (Márquez 1990). East Pacific green turtles are not restricted to coastal waters, however. After nesting at Colola, Michoacán, on November 17, 1991 a satellite-tagged female traveled northwest and arrived at the Islas Tres Marias archipelago (presumably to feed) within two weeks (R. Byles, U.S. Fish and Wildlife Service [FWS] pers. comm., 1992).

The IATTC reports that during tuna fishing cruises from Baja California to Ecuador and west to almost $150^{\circ} \mathrm{W}$, East Pacific greens are seen most frequently in this area; males, females, and juveniles were seen in this area during all times of the year. The algal beds around the Islands of Ferdinanda e Isabel in the Galapagos archipelago are an important feeding ground for the East Pacific green turtles nesting in the Islands (Green and Ortiz-Crespo 1982). The southernmost site reported of East Pacific green turtle distribution is from Desolation Island in Chile (Márquez 1990).

\section{F. Status}

Under the U.S. Endangered Species Act (ESA) of 1973, as amended, the breeding populations of Chelonia mydas from the Pacific coast of Mexico are listed as Endangered. Similarly, all populations of Chelonia mydas are classified as Endangered in the International Union for Conservation of Nature and Natural Resources' (IUCN) Red Data Book, where taxa so classified are considered to be "in danger of extinction and whose survival is unlikely if the causal factors continue operating" (Groombridge 1982). Populations of Chelonia mydas are included in Appendix I of the Convention on International Trade in Endangered Species of Wild Fauna and Flora (CITES), a designation which bans trade in specimens or products except by special permit. Such permits must show that the trade is not detrimental to the survival of the species and is not for primarily commercial purposes (Lyster 1985).

Excessive exploitation of the East Pacific green turtle throughout its range has caused a dramatic decline in numbers over the 1900s. In Michoacán, Mexico where about one third of all East Pacific green turtles nest, the population has exhibited a clear decline in numbers over the last 40 years. Similarly, East Pacific green turtles were abundant and widespread in northern Mexico feeding grounds (Gulf of California) and along the Pacific coast of Baja California as late as the 1960s. Today, East Pacific green turtles are rare in the Gulf of California and most appear to be juveniles (see Historical and Cultural Background).

In Mexico, a presidential decree (May 1990) banned the harvest of all sea turtles and their eggs, as well as trade in sea turtle products. This has drastically diminished (but not eliminated)

clandestine harvest and trade in sea turtle products. Field enforcement, however, remains 
extremely difficult. Effective 30 September 1991, Mexico became the 111th Party to CITES. Mexico ratified CITES with no reservations.

\section{G. Biological Characteristics}

\section{Migration and Movements}

The dispersal of East Pacific green turtle hatchlings from natal beaches has not been studied, but it can be assumed to include passive transport by ocean currents over vast distances.

According to tag-recovery data (as summarized by Alvarado and Figueroa 1990), East Pacific green turtle migrations occur between the northern and southern extremes of their range. Recoveries of nesting females tagged on the beaches of Michoacán have been documented from El Salvador, Guatemala, Nicaragua, Costa Rica and Colombia. Recoveries have also been documented from Mexican waters, primarily from the Gulf of California and adjacent waters, and from the coast of Oaxaca. Tag recoveries in Central America are most common from El Salvador and Guatemala. In Mexico the frequency of recovery is highest in the Gulf of California and adjacent waters. Of 37 documented recaptures during 1989-1990, 32 were incidental catches, mainly by shrimp and fish trawlers. Most of the recoveries were restricted to coastal waters, perhaps because most commercial fishing in the east Pacific occurs on the narrow continental shelf. The average depth at 13 coastal capture sites was $24.3 \pm 5.8 \mathrm{~m}$ (range $10.0-72.0 \mathrm{~m}$ ). The longest distance covered by an East Pacific green turtle prior to capture was $3,160 \mathrm{~km}$ (measured in the direct line along the coast) by a turtle tagged in Michoacán and recovered at El Faro, Charambira, Colombia in October 1986. Minimum average traveling speed is $22.5 \mathrm{~km} /$ day (range $8.0-38.0, n=7)$. A post-nesting female that was satellite-tagged at Colola in Michoacán in October 1991 traveled to Central America and was tracked for two months; she swam about 2,000 km with a daily average distance of $33 \mathrm{~km}$ (Byles et al. 1995).

Tag-recovery data indicates that at least part of the East Pacific green turtle population breeding in the Galapagos Islands is recruited from distant feeding grounds. Galapagos-tagged turtles have been recovered in the coastal waters of Costa Rica, Panama, mainland Ecuador, Colombia and Peru (Green 1984; MacFarland 1984). The Galapagos archipelago lies approximately $1,000 \mathrm{~km}$ off the coast of mainland Ecuador; thus, movements between mainland feeding and island breeding grounds involve crossing a vast expanse of open ocean. An undetermined portion of the Galapagos breeding contingent remains in the feeding grounds around the Galapagos Islands year-round (Green and Ortiz-Crespo 1982; MacFarland 1984). Some East Pacific green turtles nesting in Costa Rica may also be year-around residents (Cornelius 1986).

Data collected during tuna fishing cruises suggest that East Pacific green turtles are most frequent along a North-South band from $15^{\circ} \mathrm{N}$ to $5^{\circ} \mathrm{S}$ along $90^{\circ} \mathrm{W}$ from January through March, but most frequent between the Galapagos Islands and the Central American coast from July through September (IATTC, unpubl. data). Green (1984) suggested earlier that this observed shift might indicate migratory movement. IATTC data suggest that East Pacific greens are rare near the Mexican coast, and are only present during October through December.

A small aggregation of turtles in San Diego Bay, tentatively identified as East Pacific greens, seems to be year-round residents, and the fact that small $(<55 \mathrm{~cm} \mathrm{SCL})$ juveniles are regularly 
seen suggests that turtles are continuing to migrate into the bay (Stinson 1984; McDonald and Dutton 1993; McDonald et al. 1995).

\section{Foraging Biology and Diet}

Although East Pacific green turtle feeding grounds are not clearly delimited, the main sites appear to be the west coast of Baja California, Mexico (Scammon's Lagoon, Tortugas Bay and Magdalena Bay) (Cliffton et al. 1982), the Gulf of California (Felger et al. 1976; Márquez 1990), the Superior and Inferior lagoons in Oaxaca, Mexico (R. Márquez, Instituto Nacional de Pesca, INP, pers. comm., 1989), the Galapagos Islands (Green and Ortiz-Crespo 1982; MacFarland 1984), the Gulf of Fonseca (Honduras), and the Paracas Peninsula in Peru (Márquez 1990). According to tag-recovery information, the feeding grounds of the Michoacán breeding population are restricted to Mexico and Central America (Alvarado and Figueroa 1990), whereas the population breeding in the Galapagos Islands forages from Costa Rica south to Peru (Green and Ortiz-Crespo 1982; Green 1984; MacFarland 1984). It is not known where turtles traveling along the west coast of the United States forage; turtles in San Diego Bay feed on eelgrass and algae in the bay (Dutton and McDonald 1990a,b; McDonald et al. 1995).

Adult East Pacific green turtles are primarily herbivorous, eating sea grasses and algae, and in some areas they may feed on a variety of marine animals. Food items vary among feeding grounds. In Peru the following food items have been reported in stomach content analysis: plants (Macrocystis, Rhodymenia and Gigartina), molluscs (Nassarius, Mytilus and Semele), polychaetes, jellyfish, amphipods, and fish (sardine and anchovy) (Hays-Brown and Brown 1982). In the Galapagos Islands the following items have been reported: algae (Caulerpa, UIva) and mangrove leaves (Rhizophora mangle) (Pritchard 1971). In Ecuador, Fritts (1981) reported fish eggs in the stomach of a female turtle. In a sample of 19 turtles from Bahia de los Angeles, Gulf of California, an average of $1,230 \mathrm{~cm}^{3}$ of food per individual was obtained, composed of $90.0 \%$ algae, $1.0 \%$ animal food, and 9.0\% unidentified material (Márquez 1990). The algae found in this study were: Gracillaria, Rhodimenia, Gelidium, Grateloupia, Gigartina, Griffitsia, Sargassum, Padina, Ulva, and Cladophora. Sargassum and Gracillaria were the most abundant. In the same study, animal food items included small quantities of small molluscs, crustaceans, bryozoans, sponges, jellyfishes and echinoderms.

Casas-Andrew and Gomez-Aguirre (1980) report similar findings from off the central western coast of Mexico, with Ulva being the most abundant algae in the samples. The stomach contents of one turtle from this study consisted exclusively of the pelagic tunicate Pyrosoma. In the Infiernillo Channel (area between Tiburon Island and the mainland) in the Gulf of California, East Pacific green turtles feed on eelgrass, Zostera marina, and the sea slug, Aplesia californica (Felger and Moser 1987). Feeding habits of hatchlings and juveniles are unknown.

\section{Growth}

In the Galapagos Islands, Green (1994) found a mean growth rate of 0.40 to $0.45 \mathrm{~cm}$ per year for juveniles $40-60 \mathrm{~cm} \mathrm{SCL}$, while subadults (60.0 - 66.7 SCL) grew $0.15 \mathrm{~cm}$ per year. Growth recorded for turtles in San Diego Bay was considerably faster. Growth rates for two individuals (SCL 54.4 and $46.7 \mathrm{~cm}$ ) were 6.7 and $5.1 \mathrm{~cm} / \mathrm{yr}$, respectively, while an $86.7 \mathrm{~cm}$ female grew 3.9 $\mathrm{cm}$ in one year (McDonald et al. 1995). Green (1994) reported that since the minimum size of 
nesting turtles in the Galapagos Islands is $66.7 \mathrm{~cm} \mathrm{SCL}$, it may take some turtles at least 50 years to reach sexual maturity. Based on growth rates observed in wild turtles, age at first reproduction (minimum $81.0 \mathrm{~cm} \mathrm{SCL}$ ) for green turtles in the Hawaiian archipelago is estimated to be roughly 10-50 years depending on the feeding ground (Balazs 1982).

\section{Reproduction}

Reproduction is seasonal. In most cases gravid females migrate long distances between foraging and breeding grounds (see Migration and Movements). An exception may be the Galapagos Islands, where large numbers of East Pacific green turtles were observed copulating early in the year (IATTC, unpubl. data), and turtles are seen throughout the year. The nesting season varies with location. Nesting occurs in Michoacán between August and January, with a peak in October-November (Alvarado et al. 1985), between March and July at Socorro and Clarion islands (Márquez 1990), between December and May with a peak in February-March on the Galapagos Islands (Green and Ortiz-Crespo 1982), and possibly year-round with a peak in October-March at Playa Naranjo, Costa Rica (Cornelius 1986). On beaches shared with other nesting turtle species (e.g., Colola and Maruata in Michoacán) East Pacific green turtle nesting occurs after the nesting peak of the olive ridley and before that of the leatherback (Alvarado et al. 1985). This may reduce competition for nesting space.

In Michoacán, females typically nest in two or three year cycles and deposit between one and seven clutches per season at about 12-14 day intervals (Alvarado and Figueroa 1990). In the Galapagos Islands, females typically nest in three or five year cycles and deposit between one and five clutches per season at about 14 day intervals (Hurtado 1984). In Playa Naranjo, Costa Rica, females may nest in consecutive years and deposit at least two and perhaps as many as six nests per season at about 14 day intervals (Cornelius 1986).

Average clutch size varies geographically. In Michoacán, the average is 65 eggs (range 1-130, $n=916$ nests) (Alvarado and Figueroa 1990). In the Galapagos Islands, average clutch size is 84 eggs (range 56-152, n=30 nests) (Hurtado 1984). In Playa Naranjo, Costa Rica, average clutch size is 87 eggs (range 65-107, $n=10$ nests) (Cornelius 1976). After 42 to 62 days of incubation (Márquez 1990) hatchlings emerge mostly at night and travel quickly to the sea. Nest temperature during incubation influences the sex of hatchlings. At Michoacán, 47 East Pacific green turtle clutches were monitored in 1984 and 1985 to determine the sex ratio of emergent hatchlings. Average temperatures $<27.0^{\circ} \mathrm{C}$ (range $26.4-27.0^{\circ} \mathrm{C}$ ) during the mid-third of incubation resulted in $100 \%$ males; average temperatures between $27.5-31.0^{\circ} \mathrm{C}$ resulted in a mixed sex ratio, and those $>31.0^{\circ} \mathrm{C}$ (range $31.0-32.9^{\circ} \mathrm{C}$ ) produced $100 \%$ females (Alvarado and Figueroa 1987).

In most studied populations of sea turtles (all species), mating does not appear to occur once nesting has commenced. This is true for Chelonia mydas in Australia (Booth and Peters 1972) and Hawaii (Balazs 1980). In contrast, East Pacific green turtle mating apparently can occur both prior to and between nestings at the Michoacán rookery, and sequential mating throughout the season is implied (Alvarado and Figueroa 1991b). 


\section{Offshore Behavior}

During observations from tuna fishing cruises, East Pacific green turtles are often seen basking at the surface. Turtles seem to be most active around midday; $30 \%$ of the green turtles seen swimming were seen around noon (IATTC, unpubl. data). They were almost always seen near islands, feeding very close to the coast. Unlike olive ridleys, East Pacific greens are very rarely seen associated with floating objects. Turtles are often reported in association with fish such as dorado and sharks, but it is not always clear whether these are olive ridleys or East Pacific greens. Although East Pacific greens usually occur singly, they are frequently seen in large groups, usually near the Galapagos Islands (e.g., a group of 59 was seen in July 1991). Sampling from large groups always yielded only mature females (IATTC, unpubl. data).

\section{Health Status}

Disease in East Pacific green turtle populations has not been studied. McDonald and Dutton (1990) found early stages of what appear to be fibropapillomas (tumor disease) in several individuals of the San Diego Bay population. Green turtles residing in certain benthic habitats are afflicted by lobulated tumors (fibropapillomas) on their skin, scales, scutes, eyes, oral cavities, and viscera (Balazs and Pooley 1991). The tumors begin as small, localized lesions that rapidly grow to exceed $30 \mathrm{~cm}$ in diameter, greatly interfering with or even prohibiting swimming, feeding, breathing, or seeing. The lesions have been classified as fibropapillomas, based on established histologic criteria for tumor classification. The cause of this disease is unknown, but a herpes virus is highly suspected based on recent research (Herbst 1994). The disease has increased to epidemic proportions in Hawaii since the mid-1980s. Similar severe outbreaks in green turtles over the same time period have also been reported in Florida, several Caribbean nations, and at a few other sites worldwide. The extent of the presence of this disease has yet to be identified for the East Pacific green turtle.

Massive East Pacific green turtle mortalities, not obviously connected to human activities, have been reported along the Pacific coasts of Colombia and Costa Rica. During the fall of 1972, 73 moribund sub-adult East Pacific green turtles were observed on Nancite and Naranjo beaches in Costa Rica. No wounds were evident in the affected turtles; however, they exhibited gastro-intestinal disorders (Cornelius 1975). In February 1990, a die-off of about 200 adult female East Pacific green turtles was reported in the northern Pacific coast of Colombia. No wounds or traumas were apparent. It has been suggested that a contagious disease or drowning by trawlers may have caused the mortality (D. Amorocho in litt. to J. Woody, FWS, 27 February 1990).

\section{H. Threats}

This section presents a brief overview of threats to East Pacific green turtles, followed by summaries of major threats in each U.S.-affiliated area. A third section then presents more detailed information specific to each area where this species occurs. "Threats" to sea turtles are broadly defined as any factor that jeopardizes the survival of turtles or impedes population recovery. These threat categories are presented, but it is readily apparent that not all are equally important and that threats in one area may not be relevant in another. Consequently, each political 
jurisdiction was evaluated separately based on information received from the Pacific Sea Turtle Recovery Team and Technical Advisors. (see Table 1).

\section{Pacific Synopsis}

Lack of knowledge concerning the abundance and distribution of Chelonia in the northeastern Pacific constitutes a threat, particularly since important foraging grounds have not been specifically identified. Forage areas most likely exist in bays and inlets along the coast of Baja California (Mexico) and southern California (United States), however, these vital areas cannot be given adequate protection until they have been identified. The breeding population origins and migratory habits of East Pacific green turtles frequenting waters off the west coast of the United States are unknown. Threats to migrating turtles are, therefore, also unknown. This information is important for effective management.

\section{$\underline{\text { Regional Summaries }}$}

\section{U.S. West Coast}

Primary turtle threats: debris boat collisions incidental capture

The primary threats to the species in U.S. waters include incidental capture by coastal fisheries, boat impacts and water pollution.

Other U.S. Areas

Primary turtle threats: N/A

This regional population does not extend to other U.S. jurisdictions. 
Table 1. Threat checklist for

East Pacific green sea

turtles in the U.S.

Pacific Ocean ${ }^{\text {a }}$
Codes $1=$ major problem $-\quad=$ not current problem
$2=$ moderate problem $\quad ?=$ unknown
$3=$ minor problem $\quad P=$ known problem but extent unknown

\begin{tabular}{|c|c|c|c|c|c|c|c|c|c|c|}
\hline \multicolumn{2}{|c|}{ Threat } & $\begin{array}{l}\text { U.S. } \\
\text { West } \\
\text { Coast }\end{array}$ & Hawaii & $\begin{array}{l}\text { Amer. } \\
\text { Samoa }\end{array}$ & Guam & Palau & CNMI & RMI & FSM & Uninc. \\
\hline \multicolumn{11}{|c|}{ Marine Environment } \\
\hline 12 & Directed take & - & - & - & - & - & - & - & - & - \\
\hline 13 & Natural disasters & $P$ & - & - & - & - & - & - & - & - \\
\hline 14 & Disease/parasites & $P$ & - & - & - & - & - & - & - & - \\
\hline 15 & $\begin{array}{l}\text { Algae/Seagrass/reef } \\
\text { degradation }\end{array}$ & $P$ & - & - & - & - & - & - & - & - \\
\hline 16 & Environmental Contaminants & $P$ & - & - & - & - & - & - & - & - \\
\hline 17 & Debris (entangle/ingest) & 1 & - & - & - & - & - & - & - & - \\
\hline \multirow[t]{3}{*}{18} & Fisheries (incidental take) & & & & & & & & & \\
\hline & -domestic waters & 3 & - & - & - & - & - & - & - & - \\
\hline & -international & $?$ & - & - & - & - & - & - & - & - \\
\hline 19 & Predation & $?$ & - & - & - & - & - & - & - & - \\
\hline 20 & Boat collisions & 1 & - & - & - & - & - & - & - & - \\
\hline 21 & Marina/dock development & - & - & - & - & - & - & - & - & - \\
\hline 22 & Dredging & - & - & - & - & - & - & - & - & - \\
\hline 23 & Dynamite"fishing" & - & - & - & - & - & - & - & - & - \\
\hline 24 & Oil exploration/development & - & - & - & - & - & - & - & - & - \\
\hline 25 & Power plant entrapment & - & - & - & - & - & - & - & - & - \\
\hline 26 & Construction blasting & - & - & - & - & - & - & - & - & - \\
\hline
\end{tabular}

a There is no known nesting by this species in the United States or in any territory under U.S. jurisdiction. Therefore, only threats in the marine environment (\#12-26) are included in this table. 


\section{General Threat Information}

This section provides the supportive information used to rank the threats listed in Table 1. The first 11 threats pertain to the turtle's nesting environment, the latter 15 to the marine environment.

\section{Nesting Environment}

While no East Pacific green turtles nest in U.S. jurisdiction, it is important that the United States participate in restoration efforts of U.S. sea turtle stocks at their nesting beaches. Thus, we have chosen to add a general description of nesting beach threats, so that U.S. resource managers can make informed decisions on policies to support turtles in other political jurisdictions.

\section{Directed Take}

The harvest of sea turtles and/or their eggs for food or any other domestic or commercial use constitutes a widespread threat to these species. Removing breeding adults from a population can accelerate the extinction of local stocks, and the persistent collection of eggs guarantees that future population recruitment will be reduced. This category includes only the harvest of sea turtles (typically nesting females) and their eggs on land. Harvest at sea is discussed in a later section. (see Recovery - Section 1.1.1.1)

\section{Increased Human Presence}

Human populations are growing rapidly in many areas of the Pacific and this expansion is exerting increasing pressure on limited coastal resources. Threats to sea turtles include increased recreational and commercial use of nesting beaches, the loss of nesting habitat to human activities (e.g., pig pens on beaches), beach camping and fires, an increase in litter and other refuse, and the general harassment of turtles. Related threats, such as coastal construction, associated with increasing human populations are discussed separately. (see Recovery - Sections 1.1,1.2)

\section{Coastal Construction}

The most valuable land is often located along the coastline, particularly when it is associated with a sandy beach. Construction is occurring at a rapid rate and is resulting in a loss of sea turtle nesting areas. This section discusses construction-related threats to the region's sea turtle nesting beaches, including the construction of buildings (hotels, houses, restaurants), recreational facilities (tennis courts, swimming pools), or roads on the beach; the construction of sea walls, jetties, or other armoring activities that can result in the erosion of adjacent sandy beaches; clearing stabilizing beach vegetation (which accelerates erosion); and the use of heavy construction equipment on the beach, which can cause sand compaction or beach erosion. (see Recovery Sections 1.1.2, 1.2)

\section{Nest Predation}

The loss of eggs to non-human predators is a severe problem in some areas. These predators include domestic animals, such as cats, dogs and pigs, as well as wild species such as rats, 
mongoose, birds, monitor lizards, snakes, and crabs, ants and other invertebrates. (see Recovery - Section 1.1.3)

\section{Beach Erosion}

Weather events, such as storms, and seasonal changes in current patterns can reduce or eliminate sandy beaches, degrade turtle nesting habitat, and cause barriers to adult and hatchling turtle movements on affected beaches. (see Recovery - Sections 1.1.5.2, 1.2.1)

\section{Artificial Lighting}

Hatchling sea turtles orient to the sea using a sophisticated suite of cues primarily associated with ambient light levels. Hatchlings become disoriented and misdirected in the presence of artificial lights behind (landward of) their hatching site. These lights cause the hatchlings to orient inland, whereupon they fall prey to predators, are crushed by passing cars, or die of exhaustion or exposure in the morning sun. Nesting adults are also sensitive to light and can become disoriented after nesting, heading inland and then dying in the heat of the next morning, far from the sea. Security and street lights, restaurant, hotel and other commercial lights, recreational lights (e.g., sports arenas), and village lights, especially mercury vapor, misdirect hatchlings by the thousands throughout the Pacific every year. (see Recovery - Sections 1.1.2, 1.1.4)

\section{Beach Mining}

Sand and coral rubble are removed from beaches for construction or landscaping purposes. The extraction of sand from beaches destabilizes the coastline (e.g., reduces protection from storms), removes beach vegetation through extraction or flooding and, in severe cases, eliminates the beach completely. When mining occurs on or behind a nesting beach, the result can be the degradation or complete loss of the rookery. In addition, females can become confused when they emerge from the sea only to find themselves heading down slope into a depression formed by mining activities; too often the outcome is that the female returns to the sea without laying her eggs. Even when eggs are successfully deposited, reduced hatch success results if nests are flooded or excavated during mining. (see Recovery - Section 1.2.2)

\section{Vehicular Driving on Beaches}

Driving on the beach causes sand compaction and rutting, and can accelerate erosion. Driving on beaches used by turtles for egg-laying can crush incubating eggs, crush hatchlings in the nest, and trap hatchlings after they emerge from the nest cavity and begin their trek to the sea. In the latter case, hatchlings are exposed to exhaustion and predators when they fall into and cannot climb out of tire ruts that are typically oriented parallel to the sea. (see Recovery - Section 1.2.6)

\section{Exotic Vegetation}

Introduced species can displace native dune and beach vegetation through shading and/or chemical inhibition. Dense new vegetation shades nests, potentially altering natural hatchling sex ratios. Thick root masses can also entangle eggs and hatchlings. (see Recovery - Section 1.2.3) 


\section{Beach Cleaning}

Removal of accumulated seaweeds and other debris from a nesting beach should be accomplished by hand-raking only. The use of heavy equipment can crush turtle eggs and hatchlings and can remove sand vital to incubating eggs. (see Recovery - Section 1.2.5)

\section{Beach Replenishment}

The nourishment or replacement of beaches diminished by seawalls, storms, or coastal development can reduce sea turtle hatching success by deeply burying incubating eggs, depositing substrate (generally from offshore deposits) that is not conducive to the incubation of sea turtle eggs, and/or obstructing females coming ashore to nest by machinery, pipelines, etc. (see Recovery - Section 1.2.4)

\section{Marine Environment}

\section{Directed Take}

The harvest of juvenile and adult sea turtles for food or any other domestic or commercial use constitutes a widespread threat to these species. In particular, the exploitation of large juveniles and adults can accelerate the extinction of both local and regional stocks. This category includes only the harvest of sea turtles at sea. Harvest on the nesting beach was discussed in a previous section. (see Recovery - Section 2.1)

While the illegal take of juvenile and adult Chelonia in Mexican waters is not uncommon, no information exists on the take of this species in U.S. waters. Presumably direct take in the United States is zero.

\section{Natural Disasters}

Natural phenomena can contribute to the mortality of turtles at sea, particularly in shallow waters. Storms can alter current patterns and blow migrating turtles off course into cold water. Unseasonal warm water incursions from subtropical regions into the northeastern Pacific, known as "El Niño" events, may cause East Pacific green turtles to migrate north where they "cold stun" once they encounter colder water. El Niño events can also cause reduced food production for some turtle species which can reduce growth and fecundity. Increased numbers of stranded East Pacific green turtles reported along the coasts of California, Oregon and Washington are associated with these "EI Nino" events (Stinson 1984). (see Recovery - Sections 2.1.6, 2.1.7. 2.2.1, 2.2.2)

\section{Disease and Parasites}

There are few data to assess the extent to which disease or parasitism affects the survivability of sea turtles in the wild. The "fibropapilloma" tumor disease is widespread in the Hawailan green turtle population. This disease is characterized by grayish tumors of various sizes, particularly in the axial regions of the flippers and around the eyes. This debilitating condition can be fatal. 
Neither cause nor cure has been identified. While fibropapillomas have not been observed in the Mexican nesting population (J. Alvarado, Universidad de Michoacán, pers. comm.), some turtles have been observed with what appears to be beginning stages of the disease in San Diego Bay (McDonald and Dutton 1990). (see Recovery - Section 2.1.6 )

\section{Algae, Seagrass and Reef Degradation}

Most sea turtle species depend upon sea grass and/or coral reef habitats for food and refuge. The destruction or degradation of these habitats is a widespread and serious threat to the recovery of depleted sea turtle stocks. The general degradation of these habitats can be affected by eutrophication, sedimentation, chemical poisoning, collecting/gleaning, trampling (fishermen, skin and SCUBA divers), anchoring, etc. (see Recovery - Section 2.2)

\section{Environmental Contaminants}

Chemical contamination of the marine environment due to sewage, agricultural runoff, pesticides, solvents and industrial discharges is widespread along the coastal waters of the western United States, particularly near the populated inlets and bays of southern California where East Pacific green turtles are likely to be found. San Diego Bay, the only identified forage area for Chelonia in the eastern United States (Stinson 1984, Dutton and McDonald 1990a,b), is heavily polluted with heavy metals and PCBs. This contamination has been shown to cause lesions and mortality in fish and invertebrates, and small lesions have been observed in some of the turtles there (McDonald and Dutton 1990). Declining productivity of algal and seagrass communities can negatively impact the East Pacific green turtles that depend on these communities for nutrition. (see Recovery - Section 2.2.4)

\section{Debris (Entanglement and Ingestion)}

The entanglement in and ingestion of persistent marine debris threatens the survival of Chelonia in the eastern Pacific. Turtles become entangled in abandoned fishing gear, ropes and nets, and cannot submerge to feed or surface to breathe; they may lose a limb or attract predators with their struggling. Turtles will also ingest debris such as plastic bags, plastic sheets, plastic six-pack rings, tar balls, styrofoam, and other refuse. Necropsies of stranded turtles have revealed mortalities due to ingested garbage resulting in poisoning or obstruction of the esophagus. An adult East Pacific green turtle was recently found dead in San Diego Bay with monofilament netting tightly packed in the esophagus (Ron Rhimo, FWS, pers. comm.). (see Recovery - Section 2.1.3)

\section{Fisheries (Incidental Take)}

Turtles are accidentally taken in several commercial and recreational fisheries. These include bottom trawls commonly used by shrimp vessels in the Gulf of California, gillnets, traps, pound nets haul seines and beach seines commonly used in inshore and coastal waters of Baja California. In addition, trawls, purse seines, hook and line, driftnets, bottom and surface longlines may kill an as yet unknown number of turtles in different areas of the eastern Pacific.

Although largely undocumented, incidental catch of East Pacific green turtles by shrimp trawlers is probably a major mortality factor in Mexico (Groombridge 1982). In Central America large 
numbers of turtles are caught by shrimp trawlers mainly in Costa Rica, Guatemala and El Salvador. Quantitative estimates have been reported only for Costa Rica where in the early 1980's estimates of catch by the fleet differed among shrimp captains and ranged from $600-2,000$ annually (Cornelius 1982). Most of the turtles caught were olive ridleys. Also in Costa Rica, 73 of the 75 dead turtles (mortality probably related to shrimp trawling) that washed up on Nancite and Naranjo beaches in October and November of 1971 were young East Pacific green turtles. More recently, nearly all of the 22 turtle carcases found along the shore of Murcielago Sector of Santa Rosa Park in October 1983 were young East Pacific green turtles (Cornelius 1986). Greens comprised 14\% of the annual observed take of all species of turtles by the Hawaiian-based longline fishery between 1990-1994 (National Marine Fisheries Service [NMFS] 1995) and these may include East Pacific green turtles. The predicted annual take level by this fishery is 119 green turtles and although most are recovered and released alive, the post-release mortality remains unknown. While these numbers appear to be relatively low, they could be significant if the animals affected belong to severely depleted stocks. (see Recovery - Section 2.1.4)

\section{Predation}

Few predators, with the notable exception of orcas (killer whales), large sharks, and marine crocodiles, can consume a full-size sea turtle. Predation on hatchlings is believed to be relatively high and, again, the species most often implicated are coastal and pelagic sharks. Billfish attacks on East Pacific green turtles have also been documented (Frazier et al. 1994).

\section{Boat Collisions}

Sea turtles can be injured or killed when struck by a boat, especially an engaged propeller. Recreational equipment, such as jet skis, also pose a danger due to collisions and harassment. Eighty percent of the Chelonia deaths reported recently in San Diego Bay and Mission Bay, California were associated with evidence of boat collision (McDonald and Dutton 1992). (see Recovery - Sections $2.1 .4,2.1 .5,2.1 .7$ )

\section{Marina and Dock Development}

The development of marina and docking facilities pose direct and indirect threats to sea turtles. Direct consequences can be seen when foraging grounds and nesting beaches are dredged or otherwise permanently altered in the process of construction and maintenance. Altered current patterns and increased levels of ship traffic, pollution, and general activity which displace or injure local sea turtles constitute indirect consequences that should also be considered. Fueling facilities at marinas can result in discharge of oil and gas into sensitive estuarine habitats. There is increasing demand to install marinas and docks and develop inland coastal areas where turtles are known or are likely to exist in Baja California and southern California. (see Recovery - Sections 1.2.1, 2.2)

\section{Dredging}

Turtles may be injured or killed by active dredging machinery. Dredging may also indirectly harm turtles by destroying forage habitat. In San Diego Bay, juvenile and adult turtles spend most 
of their time motionless on the floor of dredge channels (Stinson 1984, McDonald and Dutton 1992). Periodic dredging may injure or kill these turtles. (see Recovery - Section 2.2.5)

\section{Dynamite "Fishing"}

The use of explosives to stun or kill fish destroys benthic habitat, degrading or eliminating foraging habitat and refugia for all sea turtle species (except the leatherback). (see Recovery Section 2.2.7)

\section{Oil Exploration and Development}

Oil exploration and development pose direct and indirect threats to sea turtles. A rise in transport traffic increases the amount of oil in the water from bilge pumping and disastrous oil spills. Oil spills resulting from blow-outs, ruptured pipelines, or tanker accidents, can kill sea turtles. Indirect consequences include destruction of foraging habitat by drilling, anchoring, and pollution. While oil exploration is currently limited by regulation in U.S. waters, recent proposals to allow drilling on the California coast are cause for concern. Any such exploration should be carefully evaluated for impact to East Pacific green populations before such explorations are undertaken. (see Recovery - Section 2.2.8)

\section{Power Plant Entrapment}

The entrainment and entrapment of juvenile and adult East Pacific green turtles in the saltwater cooling intake systems of coastal power plants have been documented in southern California at San Diego Gas \& Electric (SDG\&E) plants in South Bay and Encina, as well as the southern California Edison Nuclear Generating Station at San Onofre (Kent Miles, SDG\&E, pers. comm.; Joe Cordaro, NMFS, pers. comm.). Some of these turtles are released unharmed.

\section{Construction Blasting}

Blasting can injure or kill sea turtles in the immediate area. The use of dynamite to construct or maintain harbors, break up rock formations or improve nearshore access can decimate sea turtle habitat. Anchoring and related activities employed in support of the blasting can also degrade benthic habitat, grasses and other benthic communities that support sea turtles. Some types of dynamiting have minimal impact to marine life, such as placing explosive in pre-drilled holes (drilling and shooting) prior to detonation and is the standard practice to secure armor rock. (see Recovery - Section 2.2.7) 


\section{Conservation Accomplishments}

\section{Nesting Environment}

Nest poaching was very common on the Mexican Pacific coastline until 1980 when protection efforts were initiated on the major nesting grounds of the East Pacific green turtle in North America; the beaches of Colola and Maruata Bay, Michoacàn, Mexico. Prior to this the majority of the thousands of nests deposited annually were lost to poaching. Since 1980, between $85-95 \%$ of nests have been protected in beach hatcheries. The overall hatch success has exceeded $70 \%$ in most years. Along with the basic information on nest numbers, clutch size, and hatching success, the Colola-Maruata project has included additional studies of post-reproductive migrations, reproductive behavior, remigration intervals, and effects of incubation temperature on hatchling sex ratios. In 1986, Colola and Maruata beaches were declared natural reserves for the conservation of sea turtles. Any human activities within or around these reserves that may endanger nesting females, nests or nesting habitat were prohibited. At a national level, Mexico banned the harvest of sea turtles and their eggs in 1990. These actions, along with field conservation efforts, ensure the long term protection of the most important East Pacific green turtle rookery in North America.

Since the Galapágos Islands are a National Park, all East Pacific green turtle nesting beaches are completely protected and egg poaching is very rare at that archipelago.

\section{Marine Environment}

Thousands of East Pacific green turtles were captured in Mexican waters before 1984. In that year the fishery for this species was closed. Therefore, the commercial exploitation of this species is currently prohibited throughout its distributional range in the east Pacific. Incidental capture by shrimp vessels is now the single most important mortality factor for this species in the marine environment. Requiring use of TEDs (Turtle Excluder Device) by shrimp vessels in the region will certainly curtail incidental take.

In Mexico an important effort is being made by governmental agencies, non-governmental conservation organizations and educational institutions to increase public awareness of sea turtle conservation issues. The Universidad de Michoacán and Ecotonia, A.C. have produced and distributed a number of audiovisual and printed material about the East Pacific green turtle. School children in the settlements of Maruata and Colola are being introduced to the problems that the sea turtles encounter and ways in which local people can help them.

In the United States, East Pacific green turtles are protected under the Endangered Species Act (ESA) of 1973, as amended. The resident population in San Diego Bay is theoretically protected by a ban on high speed boat traffic in the south portion of the bay; however, this ban is rarely enforced. 


\section{RECOVERY}

\section{A. Recovery Objectives}

Goal: The recovery goal is to delist this regionally important population.

Recovery Criteria: To consider de-listing, all of the following criteria must be met:

1) All regional stocks that use U.S. waters have been identified to source beaches based on reasonable geographic parameters.

2) Each stock must average 5,000 (or a biologically reasonable estimate based on the goal of maintaining a stable population in perpetuity) FENA over six years.

3) Nesting populations at "source beaches" are either stable or increasing over a 25-year monitoring period.

4) Existing foraging areas are maintained as healthy environments.

5) Foraging populations are exhibiting statistically significant increases at several key foraging grounds within each stock region.

6) All Priority \#1 tasks have been implemented.

7) A management plan to maintain sustained populations of turtles is in place.

8) International agreements are in place to protect shared stocks.

Rationale: Determining quantifiable values that can be used to determine when a sea turtle stock is recovered is quite difficult. The recovery team has tried to make such recommendations as listed above based on best available information with the following conceptual guidelines:

1) The minimum nesting stock must equal a size that could not easily be eliminated by a single catastrophic event ("natural" or "man induced").

2) Nesting population trends should be long enough to minimize the effects of natural fluctuations in numbers that are characteristic of sea turtle populations. Generally this time period is equal to the estimated one generation time for each species.

3) Habitats are adequate to support population growth once threats have been reduced or eliminated.

4) If a species is to be considered for delisting, a plan must already be in force for maintaining the population in stable or increasing condition. The team was concerned that if a species was delisted, and no management plan was already in force, that the species may be driven back toward extinction too rapidly for resource management agencies to implement such plans. 


\section{B. Step Down Outline and Narrative for Recovery}

\section{NESTING ENVIRONMENT}

While it is recognized that there is no nesting by this species in U.S. jurisdiction, we felt that a description of recovery actions should be provided so that U.S. agencies could take them into account when providing support to those nations in which U.S. stocks may nest.

\subsection{Protect and manage turtles on nesting beaches.}

It is prudent to preserve the capacity of a population to recover from a depleted state by protecting nesting females, their nests and hatchlings and to preserve the quality of the nesting area. The killing of gravid females, poaching of nests, predation (native and feral), destruction of the habitat through mining, destruction of vegetation, artificial lighting, development, and increased human use all degrade the ability of depleted populations to recover. Although there are no known nesting grounds for East Pacific green turtles in the U.S. Pacific, we support the efforts of Mexico and Central American nations with nesting grounds to preserve their East Pacific green turtle nesting populations. The following tasks may be used as guidelines to enhance the reproductive ability of these sea turtle populations at the nesting grounds.

\subsubsection{Eliminate directed take of turtles and their eggs.}

Direct take of nesting turtles and their eggs has been identified as a primary threat to Pacific sea turtle populations. Eliminating this threat is required if populations are to recover.

1.1.1.1 Reduce directed take of turtles through public education and information.

While increased law enforcement will be effective in the short term, without support of the local populace, regulations will become ineffective. Education of the public as to the value of conserving sea turtles, is a very effective way of sustaining recovery efforts and providing support for enforcement of management regulations.

1.1.1.2 Increase enforcement of laws protecting turtles by law enforcement and the courts.

Lack of adequate support for law-enforcement activities which protect sea turtle populations is common, yet it must be understood that enforcement is as important as any other resource management activities. Enforcement, judicial and prosecutorial personnel must receive adequate resources as well as instruction about sea turtles and the importance of protecting turtle populations.

1.1.2 Ensure that coastal construction activities avoid disruption of nesting and hatching activities.

Coastal construction must be monitored to minimize impact on turtle beaches, both during construction, particularly during the nesting and hatching season and in the long-term. Construction equipment must not be allowed to operate on the beach, remove sand from 
the beach, or in any way degrade nesting habitat. Nighttime lighting of construction areas should be prohibited during nesting and hatching seasons. In the long-term, structures should not block the turtle's access to the beach, change beach dynamics, or encourage human activities that might interfere with the nesting process.

\subsubsection{Reduce nest predation by domestic and feral animals.}

Feral animals such as dogs and mongooses pose a severe threat to turtle nests and hatchlings. It is important that feral predators be controlled or eliminated from nesting areas. Domestic animals such as pigs or dogs can also threaten turtle nests and hatchlings, and should be controlled near nesting areas. In particular, domestic dogs should not be allowed to roam turtle nesting beaches unsupervised.

1.1.4 Reduce effects of artificial lighting on hatchlings and nesting females.

Because sea turtles (especially hatchlings) are extremely attracted to artificial lighting, lighting near nesting beaches should be placed in such a manner that light does not shine on the beach. If not, turtles may become disoriented and stray from their course.

1.1.4.1 Quantify effects of artificial lighting on hatchlings and nesting females.

It is important to quantify the impact of existing lighting in terms of nesting success and hatchling survival so that pragmatic mitigation can be applied. Also such study can be used to guide the development of effective lighting ordinances.

1.1.4.2 Implement, enforce, evaluate lighting regulations or other lighting control measures where appropriate.

Shielding of the light source, screening with vegetation, placing lights at lowered elevations and in some cases the use of limited spectrum low wavelength lighting (e.g., low pressure sodium vapor lights) are possible solutions to beach lighting problems. Such measures should be required by law and enforced.

1.1.5 Collect biological information on nesting turtle populations.

The collection of basic biological information on nesting is critical for making intelligent management decisions. Monitoring nesting success can help to identify problems at the nesting beach or elucidate important areas for protection. Analyzing population recruitment can help in understanding population status.

1.1.5.1 Monitor nesting activity to Identify important nesting beaches, determine number of nesting females, and determine population trends.

Important nesting beaches (based on actual number of nests) must be identified for special protection. Nesting beaches need to be identified by standardized surveys during the nesting season. Informational surveys with local residents and officials should be conducted to determine current or historical nesting beaches. 
1.1.5.2 Evaluate nest success and implement appropriate nest-protection measures on important nesting beaches.

One of the simplest means to enhance populations is by increasing hatchling production at the nesting beach. The first step to such an enhancement program is to determine the nesting / hatching success and to characterize factors which may limit that success. Once those limiting factors are determined, protection or mitigation measures can be implemented. If nests must be moved to prevent loss from erosion or other threats, natural rather than artificial incubation should be employed.

\subsubsection{Define stock boundaries for Pacific sea turtles.}

Because sea turtles exhibit a unique genetic signature for each major nesting assemblage, and because nesting assemblages provide an easily censused means of monitoring population status, it is useful to use genetic analysis methods to determine stock boundaries for sea turtle populations. It also enables managers to determine which stocks are being impacted by activities far removed from the nesting beaches, and thus prioritize mitigation efforts.

1.1.5.3.1

Identify genetic stock type for major nesting beach areas.

A "genetic survey" to establish the genetic signature of each nesting population must be established, before stock ranges can be determined. Such surveys are relatively simple as they require only a small blood sample from a statistically viable number of females within each nesting population.

1.1.5.3.2

Determine nesting beach origins for juvenile and subadult populations.

Because nesting populations can form the basis for stock management, it is important to be able to pair juvenile and subadult turtles with their stock units by genetic identification. DNA analyses have begun to provide scientists and managers with this sort of data.

1.1.5.3.3

Determine the genetic relationship among East Pacific green turtle populations and within the Pacific. 
The need for such study is critical to successful management of a sea turtle population as it enables resource managers to identify the entire (and often overlapping) range of each population. This type of population study can also detail the genetic diversity and viability of the populations.

\subsection{Protect and manage nesting habitat.}

The nesting habitat must be protected to ensure future generations of the species. Increased human presence and coastal construction can damage nesting habitat resulting in reduced nest success or reduced hatchling survival.

Once key nesting beaches are identified, they may be secured on a long-term basis in an assortment of ways. These may include conservation easements or agreements, lease of beaches, and in some cases, fee acquisition. Certain beaches may be designated as natural preserves. In some cases education of local residents may serve to adequately secure nesting beaches.

1.2.1 Prevent the degradation of nesting habitats caused by sea walls, revetments, sand bags, other erosion-control measures, jetties and breakwaters.

Beach armoring techniques that beach residents use to protect their beachfront properties from wave action may actually degrade nesting habitats by eroding beaches and preventing nesting by preventing access to nesting sites or preventing digging of the nest on the site. Guidelines on the proper placement of stonewalls must be proposed. Jetties and breakwaters impede the natural movement of sand and add to erosion problems in neighboring beaches. Regulations regarding beach construction and beach armoring should be reviewed to ensure that such measures are restricted or prohibited if adverse impacts to nesting are anticipated.

1.2.2 Eliminate sand and coral rubble removal and mining practices on nesting beaches.

Beach mining severely affects a nesting beach by reducing protection from storms, destroying native vegetation directly or indirectly and may completely destroy a nesting beach. Protective legislation and public education must be used to protect the substrate of the beaches.

1.2.3 Develop beach-landscaping guidelines which recommend planting of only native vegetation, not clearing stabilizing beach vegetation and evaluating the effects as appropriate.

Non-native vegetation may prevent access to nesting sites, prevent adequate nest digging, exacerbate erosion or affect hatchling sex ratios by altering incubation temperatures. Native vegetation, however, plays an important role in stabilizing the beach and creating the proper microclimate for nests. Guidelines for residents concerning the most appropriate plant species and the importance of a native plant base should be encouraged. 
1.2.4 Ensure that beach replenishment projects are compatible with maintaining good quality nesting habitat.

Sand on sea turtle beaches has particular properties which affect hatching success (ie. compaction, gas diffusion, temperature). Any addition or replacement of sand may change these properties and make it more difficult for females to nest or reduce hatchling success. As such, beach replenishment projects should be carefully considered, use materials similar to the native sands and be carried out outside the nesting season.

1.2.5 Implement non-mechanical beach cleaning alternatives.

Hand raking of beach debris, rather than using heavy machinery, should be encouraged on nesting beaches where cleaning is done for aesthetic reasons. The use of heavy machinery can adversely affect hatchlings directly and their nesting habitat.

\subsubsection{Prevent vehicular driving on nesting beaches.}

Driving on active nesting beaches should be forbidden. Vehicles cause destabilization of beaches, threaten incubating nests and leave tire ruts that hatchlings have difficulty crossing.

\section{MARINE ENVIRONMENT}

2.1 Protect and manage East Pacific green turtle populations in the marine habitat.

Protection of turtles in the marine environment is a priority that is often overlooked as enforcement is difficult and quantification of the problem problematic. However, $99 \%$ of a turtle's life is spent at sea; thus, recovery must include significant efforts to protect turtles at that time. As their distribution in the marine habitat of the U.S. Pacific is limited, we must encourage and support recovery efforts in other Pacific nations where the turtle species is found.

\subsubsection{Eliminate directed take of turtles.}

Direct take of turtles was identified as a severe threat to population recovery in the Pacific Ocean and must be eliminated if sea turtles are to recover.

Reduce directed take of turtles through public education and information.

While increased law enforcement will be effective in the short term, without support of the local populace, regulations will become ineffective. Education of the public as to the value of conserving sea turtles, is a very effective way of sustaining recovery efforts and providing support for enforcement of management regulations. (Also see Section 4).

2.1.1.2 Increase the enforcement of protective laws on the part of law enforcement and the courts. 
One of the major threats identified for turtle populations in the Pacific was the illegal harvest of turtles both on the nesting beach and in the water. Rigorous efforts in law enforcement should be undertaken immediately to reduce this source of mortality. Such efforts need to include training of enforcement personnel in the importance of protecting turtles, as well as supplying such personnel with adequate logistical support (boats, communication and surveillance equipment etc.). Judges and prosecutors must also be educated in the importance of these matters.

\subsubsection{Determine distribution, abundance, and status in the marine environment.}

In its review of information on sea turtle populations in the Pacific, the Recovery Team found that lack of accurate information on distribution and abundance was one of the greatest threats to sea turtle populations. While excellent information on nesting for some areas of Mexico is available, particularly in Michoacán, there is a general lack of information on the regional population size and status. We consider that gathering of basic information on distribution and abundance should be a very high priority activity toward the recovery of East Pacific green turtle populations.

2.1.2.1 Determine the distribution and abundance of post-hatchlings, juveniles and adults.

While little is known about the distribution of nesting beaches for the East Pacific green turtle, even less is understood about distribution of foraging adult and juvenile populations. Quantitative surveys of foraging areas to determine their abundance, and to identify essential habitat is of significant importance for restoration of East Pacific green turtle populations.

2.1.2.2 Determine adult migration routes and inter-nesting movements.

Like all species of sea turtle (with the possible exception of the Flatback turtle, Natator depressus), East Pacific green turtles migrate from foraging grounds to nesting beaches. These migrations often mean that the turtles move through a variety of political jurisdictions where regulations regarding the stewardship of the species may vary. To preclude the problem of contradictory management strategies by these various jurisdictions, it is important to determine the migration routes East Pacific green turtles follow between nesting and foraging areas. Satellite telemetry studies of both males and females are needed.

2.1.2.3 Determine growth rates and survivorship of hatchlings, juveniles, and adults, and age at sexual maturity.

Understanding the rates of growth and survivorship of turtle populations is crucial to the development of appropriate population models. Such models are important in understanding population status and how best to efficiently apply management efforts, in restoring depleted populations. For example, the application of stagebased modeling (Crouse et al. 1987) indicated that not enough effort was being expended on protecting juvenile sized loggerhead sea turtles in the southeastern 
United States and that without such protection, extensive nesting beach protection was having less positive benefit. A similar approach to understanding East Pacific green turtle populations should be undertaken, and used to guide restoration policy.

Identify current or potential threats to adults and juveniles on foraging grounds.

Little is known about threats to foraging populations of East Pacific green turtles. Studies on such threats should be undertaken immediately.

2.1.3 Reduce the effects of entanglement and ingestion of marine debris.

Entanglement due to abandoned or unmonitored fishing gear, as well as the ingestion of man-made debris is a significant problem in the marine environment.

2.1.3.1 Evaluate the extent to which sea turtles ingest persistent debris and become entangled.

Quantification of the extent to which sea turtles are impacted by marine debris should be undertaken as a first step to mitigating or preventing such impacts. The benefits of such work are that it allows the prioritization of recovery activities and it allows the activities to be efficiently targeted at the problem.

2.1.3.2 Evaluate the effects of entanglement and ingestion of persistent debris on health and viability of sea turtles.

Because of the remote nature of turtle/debris interactions, the acute and chronic effects of such interaction are not often understood. Turtles may not die immediately after ingesting certain materials, but may become debilitated. Studies to further understand the impacts of such interactions, and what age classes are affected most severely, should be undertaken immediately. As with quantifying the extent to which sea turtles ingest debris, such a program allows recovery efforts to be more efficient.

2.1.3.3 Formulate and implement measures to reduce or eliminate persistent debris and sources of entanglement in the marine environment.

Once the problem of marine debris has been identified and quantified, it is important to implement (and enforce) a program to reduce the amount of debris in the marine environment, ie. removing the problem entirely.

2.1.4 Monitor and reduce incidental mortality in the commercial and recreational fisheries.

For some areas, incidental take in fisheries has been identified as a severe threat. These mortalities are often associated with international fleets operating on the high seas, but for the coastal dwelling East Pacific green turtle it is probably most significant in nearshore waters. Monitoring of turtle take by fisheries is extremely important for two reasons. First, it allows resource managers a means to quantify the extent of the problem, and by the very 
act of monitoring, tends to cause commercial fishermen to be more aware of the concern over incidental take, and thereby encourage reduced take. The choice method for monitoring take is through the use of an unbiased observer program. Voluntary logbooks have not proven a reliable technique for quantifying incidental catch in commercial fisheries. Implementation of mortality reduction activities includes the use of TEDs in shrimp trawler fisheries.

2.1.5 Eliminate the harassment of turtles at sea through public education and enforcement.

Activities such as "petting" turtles and chasing them while snorkeling and scuba diving, water skiing, jet skis, vessel traffic, and vessel anchoring may disturb or displace turtles. These factors should be regulated or controlled to eliminate negative impacts, especially in sensitive and high density foraging and resting areas.

2.1.6 Study the impact of diseases on turtles.

Little is known about diseases in sea turtles, but there has been recent evidence that it may be a limiting factor in certain populations. Disease origin and transmission may not be limited to the marine environment.

2.1.6.1 Determine prevalence of fibropapillomatosis in population.

Debilitating and life threatening tumors are known to occur in populations of green turtles. The magnitude of this disease during recent years has increased substantially in some areas although the extent of the disease is unknown in the east Pacific green turtle. The etiology of the disease and effects as they relate to the viability of the population are presently unknown and need to be studied.

2.1.6.2 Investigate parasites and other infectious agents.

A variety of other diseases and parasites may be affecting sea turtles. The prevalence of such infections, their impact on sea turtles, and modes of transmissions need to be studied. Parasites include internal parasites such as blood flukes, external parasites such as leeches (Ozobranchus) and burrowing barnacles (Stephanolepas), and certain bacterial infections such as Vibrios.

\subsubsection{Maintain carcass stranding network.}

Stranding networks are operated generally by volunteers who monitor beaches for stranded animals. Such networks can be useful for alerting managers to incidents causing high mortality, such as an increased fishery take or disease problems, as well as providing some basic biological data.

2.1.8 Centralize administration and coordination of tagging programs.

In general, government resource management agencies can provide the continuity required to coordinate tagging programs. The responsibility of any such agency is that they act as 
a central distribution point for tags, tagging training and database management. It is critically important that the coordinating agency: 1 ) provides adequate staff to keep the program organized and respond to tag returns immediately, and 2) remain in existence for many years $(20+)$. Without such a commitment, tagging programs have very limited usefulness, and before initiation of such a program it should be considered carefully on its scientific merits. It must be remembered that sea turtles are long-lived animals, and the most valuable information yielded by any tagging program comes from turtles which have carried identification tags for many years. Short-term tagging projects are at best very limited in the information they yield and at worst are nothing more than a form of undue harassment to the turtles.

Centralization of tag records is useful as it makes the most efficient use of limited personnel resources, allows standardization of techniques, and can act as a screening mechanism to ensure that tagging is done for valid scientific reasons.

2.2 Protect and manage marine habitat, including foraging habitats.

East Pacific green turtles inhabit a variety of marine habitats, although we are most familiar with their coastal habitat. Increased human presence in this and other sea turtle habitats have contributed to habitat degradation, primarily by coastal construction, increased recreational and fisheries use, and increased industrialization. Habitat loss and degradation must be prevented or slowed.

\subsubsection{Identify important marine habitats}

These areas may include hatchling, juvenile and adult foraging areas and migratory range for all age classes. (Many of these areas will first need to be identified through actions in Section 2.1.2.1 and 2.1.2.2.)

\subsubsection{Ensure the long-term protection of marine habitat.}

Once marine habitats are identified, sea turtle range, refugia and foraging habitats (Sargassum beds, coral reefs or seagrass and algal beds, estuarine habitats) need to be protected to ensure long-term survival for the species. Habitats identified as important or critical should be designated as marine sanctuaries or preserves, while others may require close monitoring. The public needs to be educated on the importance of preserving these habitats.

2.2.3 Assess and prevent the degradation or destruction of reefs and seagrass beds caused by boat groundings, anchoring, and trampling by fishermen and divers.

This is not an issue for the East Pacific green turtle due to minimum amounts of such habitat within the species distribution.

2.2.4 Prevent the degradation of reef habitat caused by environmental contaminants such as sewage and other pollutants. 
This is not an issue for the East Pacific green turtle due to minimum amounts of such habitat within the species distribution.

2.2.5 Prevent the degradation or destruction of marine habitats caused by dredging or disposal activities.

Dredging causes mechanical destruction of benthic habitats, adds suspended sediments that may damage algae and seagrasses and disposal of dredged materials smothers existing flora and fauna. Some types of dredging also kill turtles directly.

2.2.6 Prevent the degradation or destruction of important habitats caused by upland and coastal erosion and siltation.

These processes, often made worse by coastal construction, adversely affect coastal habitats by disrupting vital trophic processes, reducing productivity and reducing species diversity. Minimum water standards upstream must be maintained. Land-use decisions must take this into account and associated projects where erosion and siltation occur must be monitored.

2.2.7 Prevent the degradation or destruction of reefs by dynamite fishing and construction blasting.

Blasting of any nature physically damages reefs and may kill turtles. It must be monitored and/or restricted.

2.2.8 Prevent the degradation of coastal habitats caused by oil transshipment activities.

Oil spills from tankers are a possible threat both to coastal and pelagic habitats. Also, groundings or collisions of tankers and other petroleum industry vessels may physically damage reefs, perhaps more so than other vessels because of their sheer size (see Section 2.2.3). The oil and gas industry should take necessary preventive measures (e.g. double hulled tankers). Oil spill response teams should be identified for all likely areas.

2.2.9 Identify other threats to marine habitat and take appropriate actions.

Such threats to sea turtle habitat that do not fit in the previous sections or new threats must be considered and addressed.

\section{ENSURE PROPER CARE IN CAPTIVITY.}

Captive care of sea turtles is common in the Pacific. Most of this care is in the form of formal rearing programs. Depending on the scale of such activities such captivity can be harmful to the wild population due to excess take from the wild, or from the potential introduction of exotic diseases or unfit genetic stocks to the wild population. Captive care should be carefully regulated to minimize such problems, and all release programs should rigorously monitor the status of released turtles to ensure their proper integration into the wild. It should be noted that to be 
deemed successful, wild turtles should be shown not only to survive in the wild but should also successfully reproduce. If released turtles do not reproduce, such populations will never be self sustaining.

3.1 Develop standards for the care and maintenance of sea turtles, including diet, water quality, tank size, and treatment of injury and disease.

Standards should be developed by NMFS or other appropriate agencies. Once developed, these criteria should be published and set as requirements for any sea turtle holding facility. Facilities that comply with the criteria will receive permits to hold turtles and be inspected for compliance. A manual for diagnosis and treatment of sea turtle diseases should be compiled, published and distributed to holding facilities.

\subsection{Establish a catalog of all captive sea turtles to enhance use for research and education.}

The FWS and NMFS should establish a catalog of turtles at all known facilities and include basic biological data and genetic origin.

\subsection{Designate rehabilitation facilities.}

FWS, NMFS and other appropriate agencies should designate these facilities based on the above criteria. Designation should be based on availability of appropriate veterinary personnel, compliance with standards of care and annual inspections. Recommendations should be made on when and where hatchlings or adults should be released based on the origin of rehabilitated turtles, as determined by genetic analysis (Encalada et al. 1994).

\section{INTERNATIONAL COOPERATION.}

4.1 Support existing international agreements and conventions to ensure that turtles in all lifestages are protected in foreign waters.

Considering that East Pacific green turtles migrate outside of U.S. territorial waters during at least part of their life cycle, an effective recovery plan must include supporting existing cooperative agreements with other nations to protect the species. Existing agreements include CITES (see next section, adopted 1973), the Convention on Nature Protection and Wildlife Preservation in the Western Hemisphere (adopted 1940), the ASEAN Agreement on the Convention of Nature and Natural Resources (adopted 1985), the Convention for the Protection of the Natural Resources and Environment of the South Pacific Region (SPREP convention, adopted 1986), as well as a number of conventions concerning marine pollution (Eckert, 1993).

4.2 Encourage ratification of CITES for all non-member Pacific countries, compliance with CITES requirements, and removal of sea turtle trade reservations held by member nations.

CITES is a comprehensive wildlife treaty signed by many countries that regulates and prohibits commercial import and export of wild plant and animal species that are threatened by trade. In the north Pacific signatories include 18 countries (Eckert, 1993). It is one of the most 
powerful international agreements concerning threatened species. The U.S. State Department, Department of Commerce and Department of Interior should work with Pacific nations to encourage non-member countries to become signatories and demand compliance with CITES requirements on sea turtles from all signatories.

4.3 Develop new international agreements to ensure that turtles in all life-stages are protected in foreign waters.

New agreements must be outlined by the FWS and NMFS, and pursued by the State Department and Department of the Interior.

4.4 Develop or continue to support informational displays in U.S. airports and ports of entry which have direct flights to Mexico and Latin America.

Airports are particularly good avenues for information about illegal trade in tortoise and tortoiseshell paraphernalia, as well as general information on sea turtle conservation. If travelers don't purchase the items, the market for them may decrease. Agencies such as NMFS, FWS and the U.S. Customs Service should collaborate on display content and placement. 


\section{REFERENCES CITED}

Alvarado, J., and A. Figueroa. 1987. The ecological recovery of sea turtles of Michoacan, Mexico. Special attention: the black turtle, Chelonia agassizii. Final Report 1986-1987 submitted to U.S.F.W.S. and W.W.F. - U.S. 46 pp. + tables/figs.

Alvarado, J., and A. Figueroa. 1989. The ecological recovery of sea turtles of Michoacan, Mexico. Special attention: the black turtle, Chelonia agassizii. Final Report 1988-1989 submitted to U.S.F.W.S. and W.W.F. - U.S. 82 pp. + tables/figs.

Alvarado, J., and A. Figueroa. 1990. The ecological recovery of sea turtles of Michoacan, Mexico. Special attention: the black turtle, Chelonia agassizii. Final Report 1989-1990 submitted to U.S.F.W.S. and W.W.F. - U.S. 97 pp. + tables/figs.

Alvarado, J., and A. Figueroa. 1991a. Recovery of the black turtle in Michoacan, Mexico: an integrated conservation approach. Mar. Turtle Newsl. 53:1-3.

Alvarado, D.J., and A. Figueroa L. 1991b. Comportamiento reproductivo de la tortuga negra Chelonia agassizii. Ciencia y Desarrollo 17(98):43-49.

Alvarado, J., A. Figueroa, and H. Gallardo. 1985. Ecologia y conservacion de las tortugas marinas de Michoacan, Mexico. Cuadernos de Investigacion, UMSNH, Mexico, 4:44 pp.

Awbrey, F.T., S. Leatherwood, E.D. Mitchell, and W. Rogers. 1984. Nesting green sea turtles (Chelonia mydas) on Isla Clarion, Islas Revillagigedos, Mexico. Bull. South. Calif. Acad. Sci. 83(2):69-75.

Balazs, G.H. 1980. Synopsis of biological data on the green turtle in the Hawaiian Islands. U.S. Dep. Commer., NOAA Tech. Memo. NMFS-SWFC-7 141 pp.

Balazs, G.H. 1982. Growth rates of immature green turtles in the Hawaiian archipelago. Pages 117-125 in K.A Bjorndal (ed.), Biology and Conservation of Sea Turtles. Smithsonian Inst. Press, Washington, D.C. 583 pp.

Balazs, G. H. and S.G. Pooley. 1991. Research plan for marine turtle fibropapilloma. Results of a December 1990 workshop. NOAA Tech. Memo. NMFS -SWFSC-156 113 pp.

Booth, J., and J. Peters. 1972. Behavioral studies on the green turtle (Chelonia mydas) in the sea. Anim. Behav. 20:808-812.

Bocourt, M. 1868. Description de quelques cheloniens nouveaux appartenant a la faune Mexicaine Annales des Sciences Naturelles Zoologie et Biologie Animale. 10:121-122 .

Bowen, B.W., A.B. Meylan, J.P. Ross, C.J. Limpus, G.H. Balazs, and J.C. Avise. 1992. Global population structure and natural history of the green turtle (Chelonia mydas) in terms of matriarchal phylogeny. Evolution 46(4):865-881. 
Brongniart, A. 1800. Essaid'une classification naturelle des reptiles. Bull. Sci. Soc. Philomat. Paris 3(2):81-82, 89-91.

Byles, R., J. Alvarado, and D. Rostal. 1995. Preliminary analysis of post-nesting movements of the black turtle (Chelonia agassizi) from Michoacan Mexico. Pages 12-13 in: Proc. of the Twelfth Annual Workshop on Sea Turtle Biology and Conservation. NOAA Tech. Memo. NMFS-SEFCS-361. 274 pp.

Caldwell, D.K. 1962. Sea turtles in Baja California waters (with special reference to those of the Gulf of California), and the description of a new subspecies of North-eastern Pacific green turtle. Contrib. Science No. 61:3-31. Los Angeles County Museum.

Caldwell, D.K. 1963. The sea turtle fishery of Baja California, Mexico. Calif. Fish Game 49(3):140-151.

Carl, G.C. 1955. The green turtle in British Columbia. Report of the Provincial Museum of Natural History and Anthropology (British Columbia). 1954:77-78.

Casas-Andrew, G., and S. Gomez-Aguirre. 1980. Contribucion al conocimiento de los habitos alimenticios de Lepidochelys olivacea y Chelonia mydas agassizi (Reptilia, Cheloniidae) en el Pacifico mexicano. Bolm. Inst. Oceanogr., S. Paulo, 29(2):87-89.

Cliffton, K., D.O. Cornejo, and R.S. Felger. 1982. Sea turtles of the Pacific coast of Mexico. Pages 199-209 in K.A. Bjorndal (ed.), Biology and Conservation of Sea Turtles. Smithsonian Inst. Press, Washington, D.C. 583 pp.

Cornelius, S.E. 1975. Marine turtle mortalities along the Pacific coast of Costa Rica. Copeia 1:186-187.

Cornelius, S.E. 1976. Marine turtle nesting activity at Playa Naranjo, Costa Rica. Brenesia $8: 1-27$.

Cornelius, S.E. 1982. Status of sea turtles along the Pacific coast of Middle America. Pages 211-219 in K.A. Bjorndal (ed.), Biology and Conservation of Sea Turtles. Smithsonian Inst. Press, Washington, D.C. 583 pp.

Cornelius, S.E. 1986. The sea turtles of Santa Rosa National Park. Fundacion de Parques Nacionales Costa Rica. 64 pp.

Crouse, O.T., Crowder, L.B. and Caswell, H. 1987. A stage based population model for loggerhead sea turtles and implications for conservation. Ecology 68(5):1412-1423.

Dutton, P.H., and D.L. McDonald. 1990a. Sea turtles present in San Diego Bay. Pages 139-141 in T. H. Richardson, J.I. Richardson, and M. Donnelly (compilers), Proc. Tenth Annual Workshop on Sea Turtle Biology and Conservation. U.S. Dep. Commer., NOAA Tech. Memo. NMFS-SEFC-278. 
Dutton, P.H., and D.L. McDonald. 1990b. Status of sea turtles in San Diego Bay, $1989-1990$ Final Report. Sea World Research Institute Technical Report \#90-225. 18 pp.

Dutton, P.H., and D. McDonald. 1992. Tagging studies of sea turtles in San Diego Bay, 1990 1991. Pages 35-38 in Proc. Eleventh Annual Workshop on Sea Turtle Biology and Conservation. U.S. Dep. Commer., NOAA Tech. Memo. NMFS-SEFC-304.

Dutton, P.H., S.K. Davis, T. Guerra, and D.W. Owens. 1996. Molecular phylogeny for marine turtles based on sequences of the ND4-leucine tRNA and control regions of mitochondrial DNA. Mol. Phylogenet. Evol. 5:511-521.

Dutton, P.H., S.K. Davis, D.L. McDonald, and T. Guerra. 1994. A genetic study to determine the origin of the sea turtles in San Diego Bay, California. Pages 55-56 in B.A. Schroeder and B.E. Witherington (compilers), Proceedings of the Thirteenth Annual Symposium on Sea Turtle Biology and Conservation. NOAA Tech. Memo. NMFS-SEFSC-341. 281 pp.

Eckert, K.L. 1993. The biology and population status of marine turtles in the north Pacific Ocean. NOAA Tech. Memo. NMFS-SWFSC-186. 156 pp.

Encalada, S.E., Eckert, S.A., and Bowen, B.W. 1994. Forensic applications of mitochondrial DNA markers: origin of a confiscated green turtle. Mar. Turtle Newsl. 66:1-3.

Felger, R.S., K. Cliffton, and P.J. Regal. 1976. Winter dormancy in sea turtles: independent discovery and exploitation in the Gulf of California by two local cultures. Science 191:283-285.

Felger, R.S., and M.B. Moser. 1987. Sea turtles in Seri Indian culture. Environ. Southwest, Fall 1987:18-21.

Figueroa, A. 1989. Contribucion a la determinacion del status taxonomico de la tortuga negra (Chelonia agassizii Bocourt, 1868) de Michoacan, Mexico. UMSNH Escuela de Biologia, (Tesis Prof.). 73 pp.

Frazier, J.G., H. Fierstine, S.C. Beavers, F. Achaval, H. Suganuma, R.C. Pitman, Y. Yamaguchi, and C.Ma. Prigioni. 1994. Impalement of marine turtles (Reptilia, Chelonia: Cheloniidae and Dermochelyidae) by billfishes (Osteichthyes, Perciformes: Istiophoridae and Xiphiidae). Env. Biol. of Fishes 39:85-96.

Fritts, T.H. 1981. Pelagic feeding habits of turtles in the eastern Pacific. Mar. Turtle Newsl. 17:4-5.

Green, D. 1984. Long-distance movements of Galapagos green turtles. J. Herpetol. 18(2):121-130.

Green, D. 1994. Galapagos sea turtles: An overview. Pages 65-68 in B. A. Schroeder and B. E. Witherington (compilers), Proceedings of the Thirteenth Annual Symposium on Sea Turtle Biology and Conservation. NOAA Tech. Memo. NMFS-SEFSC-341. 281 pp. 
Green, D., and F. Ortiz-Crespo. 1982. Status of sea turtle populations in the central eastern Pacific. Pages 221-233 in: K.A. Bjorndal (ed.), Biology and Conservation of Sea Turtles. Smithsonian Inst. Press, Washington, D.C. 583 pp.

Groombridge, B. (compiler). 1982. The IUCN Amphibia-Reptilia Red Data Book, Part I: Testudines, Crocodylia, Rhyncocephalia. Intl. Union for the Conservation of Nature and Natural Resources (IUCN), Gland, Switzerland. $426 \mathrm{pp}$.

Groombridge, B., and R. Luxmoore. 1989. The green turtle and hawksbill (Reptilia: Cheloniidae): world status, exploitation and trade. CITES Secretariat, Lausanne, Switzerland. $601 \mathrm{pp}$.

Hays-Brown, C., and W.M. Brown. 1982. Status of sea turtles in the southeastern Pacific: emphasis on Peru. Pages 235-240 in K.A. Bjorndal (ed.), Biology and Conservation of Sea Turtles. Smithsonian Inst. Press, Washington, D.C. 583 pp.

Herbst, L.H. Fibropapillomatosis of marine turtles. 1994. Annual Review of Fish Diseases 4: 389425.

Hurtado, M. 1984. Registros de anidacion de la tortuga negra, Chelonia mydas en las Islas Galapagos. Bol. Cientifico y Tecnico, Instituto Nacional de la Pesca. Guayaquil, Ecuador. $\mathrm{VI}(3): 77-106$.

Kamezaki, N. and Matsui, M. 1995. Geographic variation in skull morphology of the green turtle, Chelonia mydas, with a taxonomic discussion. Journal of Herpetology; 29(1): 51-60.

Karl, S.A., B.W. Bowen, and J.C. Avise. 1992. Global population genetic structure and malemediated gene flow in the green turtle (Chelonia mydas): RFLP analysis of anonymous nuclear loci. Genetics 131: 163-173.

Linnaeus, C. 1758. Systema naturae per regna tria naturae, secundum classes, ordines, genera, species, cum characteribus, differentiis, synomymis, locis. Ed. 10, Tomus 1. L. Salvii, srockholm, Sweden, $823 \mathrm{pp}$.

Loshbaugh, D. 1993. Dead turtle may have set northern record. Homer News, October 28, 1993.

Lyster, S. 1985. International wildlife law: an analysis of international treaties concerned with the conservation of wildlife. The Research Centre for International Law, Univ. Cambridge. Grotius Publications Ltd., Cambridge. 470 pp.

MacFarland, C. 1984. Population ecology of the East Pacific green turtle (Chelonia mydas agassizi) in the Galapagos Islands. Nat. Geographic Research Reports (16):463-476.

Márquez M., R. 1990. Sea turtles of the world. An annotated and illustrated catalogue of sea turtle species known to date. FAO Species Catalog, FAO Fisheries Synopsis 11(125):81 pp.

McDonald, D., and P. Dutton. 1990. Fibropapillomas on sea turtles in San Diego Bay, California. Mar. Turtle Newsl. 51:9-10. 
McDonald, D., and P. Dutton. 1992. Status of sea turtles in San Diego Bay, 1990 - 1992 Final Report to the U.S. Fish and Wildlife Services. $16 \mathrm{pp}$.

McDonald, D., and P. Dutton. 1993. Status of sea turtles in San Diego Bay, 1991-1993 Progress Report. Report to the San Diego County Dept. of Parks and Recreation, Fish and Wildlife Advisory Commission. 5 pp.

McDonald, D.L., P.H. Dutton, D. Mayers and K. Merkel. 1995. Review of the green turtles of South San Diego Bay in relation to the operations of the SDG\&E South Bay Power Plant. Doc 94-045-01. Prepared for San Diego Gas and Electric Co. C941210311. San Diego, CA.

National Marine Fisheries Service. 1995. Annual report on the biological opinion of June 25, 1994 concerning the take of sea turtles in the Hawaii longline fishery. Unpublished report. 11 $\mathrm{pp}$.

O'Donnell, J. 1974. Green turtle fishery in Baja California waters: history and prospect. Masters Thesis, California State University, Northridge. 119 pp.

Parsons, J. 1962. The Green Turtle and Man. Univ. Florida Press, Gainesville. 126 pp.

Peters, J. 1956. The eggs (turtle) and I. The Biologist (39):21-24.

Pritchard, P.C.H. 1971. Galapagos sea turtles-preliminary findings. J. Herpetol. 5:1-9

Stinson, M.L. 1984. Biology of sea turtles in San Diego Bay, California, and in northeastern Pacific Ocean. Master of Science thesis, San Diego State Univ., California. 578 pp.

Zamora, R. 1990. Relacion de la humedad del ambiente incubatorio en el avivamiento de Chelonia agassizii en la playa de Colola, Michoacan, Mexico. UMSNH. Escuela de Biologia (Tesis Prof.), 43 pp. 


\section{IMPLEMENTATION SCHEDULE}

The Implementation Schedule outlines management and research actions and estimated costs for the U.S. East Pacific green turtle recovery program, as set forth in this recovery plan. It is a guide for meeting the objectives discussed in Part II of this plan. This schedule indicates wherever possible, task priority, task numbers, task descriptions, duration of tasks, the agencies responsible for committing funds, and lastly, estimated costs. The agencies responsible for committing funds are not, necessarily, the entities that will actually carry out the tasks. The actions identified in the implementation schedule, when accomplished, should protect habitat for the species, stabilize the existing populations, and increase the population sizes and numbers. Monetary needs for all parties involved are identified to reach this point, whenever feasible.

Priorities in column 3 of the following Implementation Schedule are assigned as follows:

Priority 1 -

An action that must be taken to prevent extinction or to prevent the species from declining irreversibly in the foreseeable future.

Priority 2 -

An action that must be taken to prevent significant decline in species population/habitat quality or some other significant negative impact short of extinction.

Priority 3 -

All other actions necessary to provide for full recovery of the species.

\section{KEY to Implementation Table Abbreviations:}

$\begin{array}{lll}\text { CNMI } & = & \text { Commonwealth of the Northern Mariana Islands } \\ \text { COE } & = & \text { U.S. Army Corp of Engineers } \\ \text { DOC } & = & \text { U.S. Department of Commerce } \\ \text { DOI } & = & \text { U.S. Department of Interior } \\ \text { DOS } & = & \text { S.S. Department of State (primarily as a conduit for negotiations and } \\ & = & \text { U.S. Environmental Protection Agency } \\ \text { EPA } & = & \text { Federated States of Micronesia } \\ \text { FSM } & \text { FW. Fish \& Wildlife Service } \\ \text { FW } & = & \text { Not applicable } \\ \text { NA } & =\quad \text { National Marine Fisheries Service } \\ \text { NMFS } & = & \text { Republic of the Marshall Islands } \\ \text { NRCS } & =\end{array}$




\begin{tabular}{|c|c|c|c|c|c|}
\hline \multirow{11}{*}{ 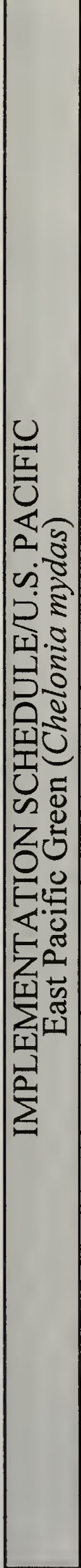 } & 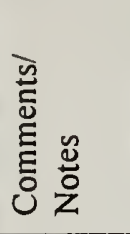 & 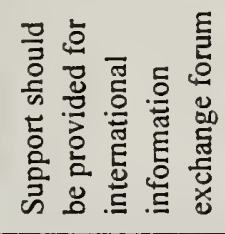 & 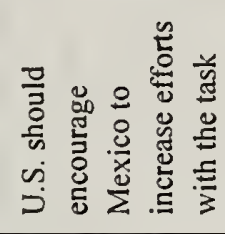 & 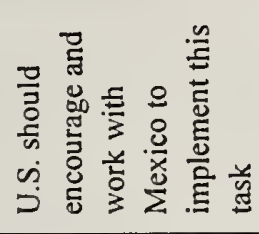 & 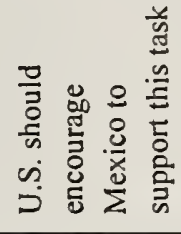 \\
\hline & $\approx$ & त & & & \\
\hline & 剀 & శి & & & \\
\hline & 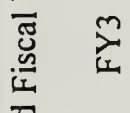 & त) & & & \\
\hline & 壱 & $\stackrel{\sim}{\circ}$ & & & \\
\hline & $\begin{array}{l}\overrightarrow{\vec{J}} \\
\stackrel{\Xi}{\Xi}\end{array}$ & त) & & & \\
\hline & 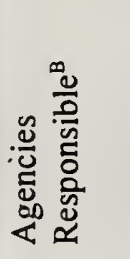 & 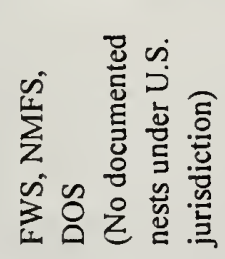 & 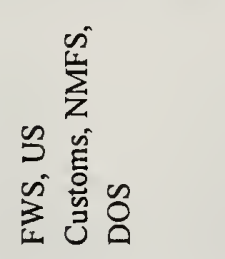 & 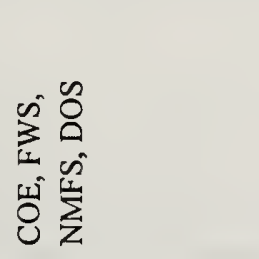 & $\begin{array}{l}0 \\
0 \\
0 \\
0 \\
3 \\
1\end{array}$ \\
\hline & 总高 & 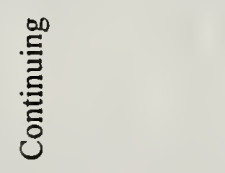 & 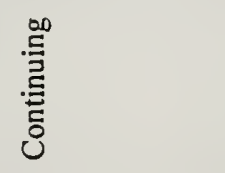 & 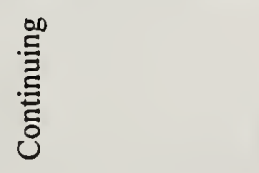 & 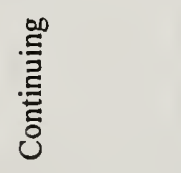 \\
\hline & 育 & $\cong$ & $\Xi$ & $\widehat{\complement}$ & $\widehat{d}$ \\
\hline & 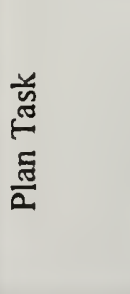 & 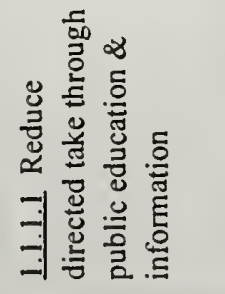 & 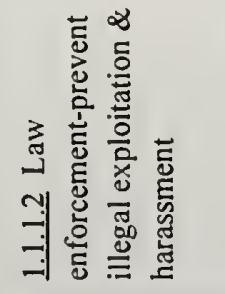 & 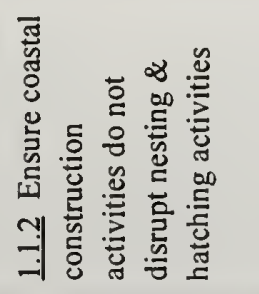 & 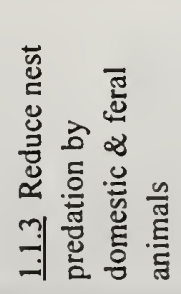 \\
\hline & 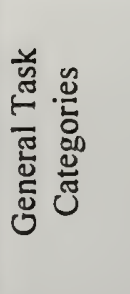 & 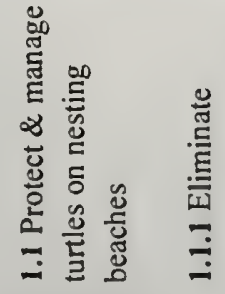 & 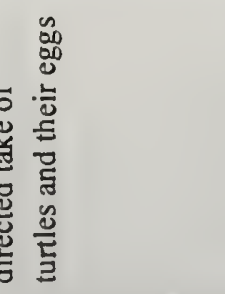 & 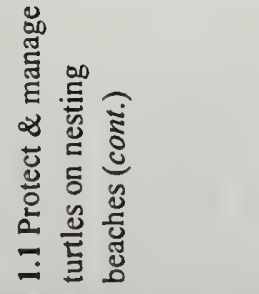 & \\
\hline
\end{tabular}

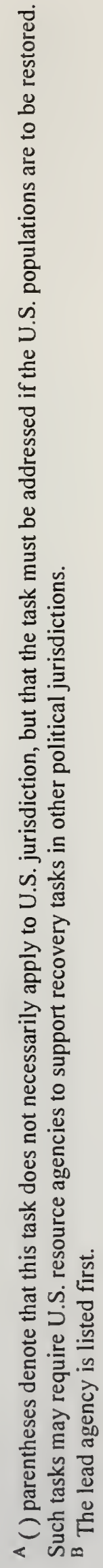



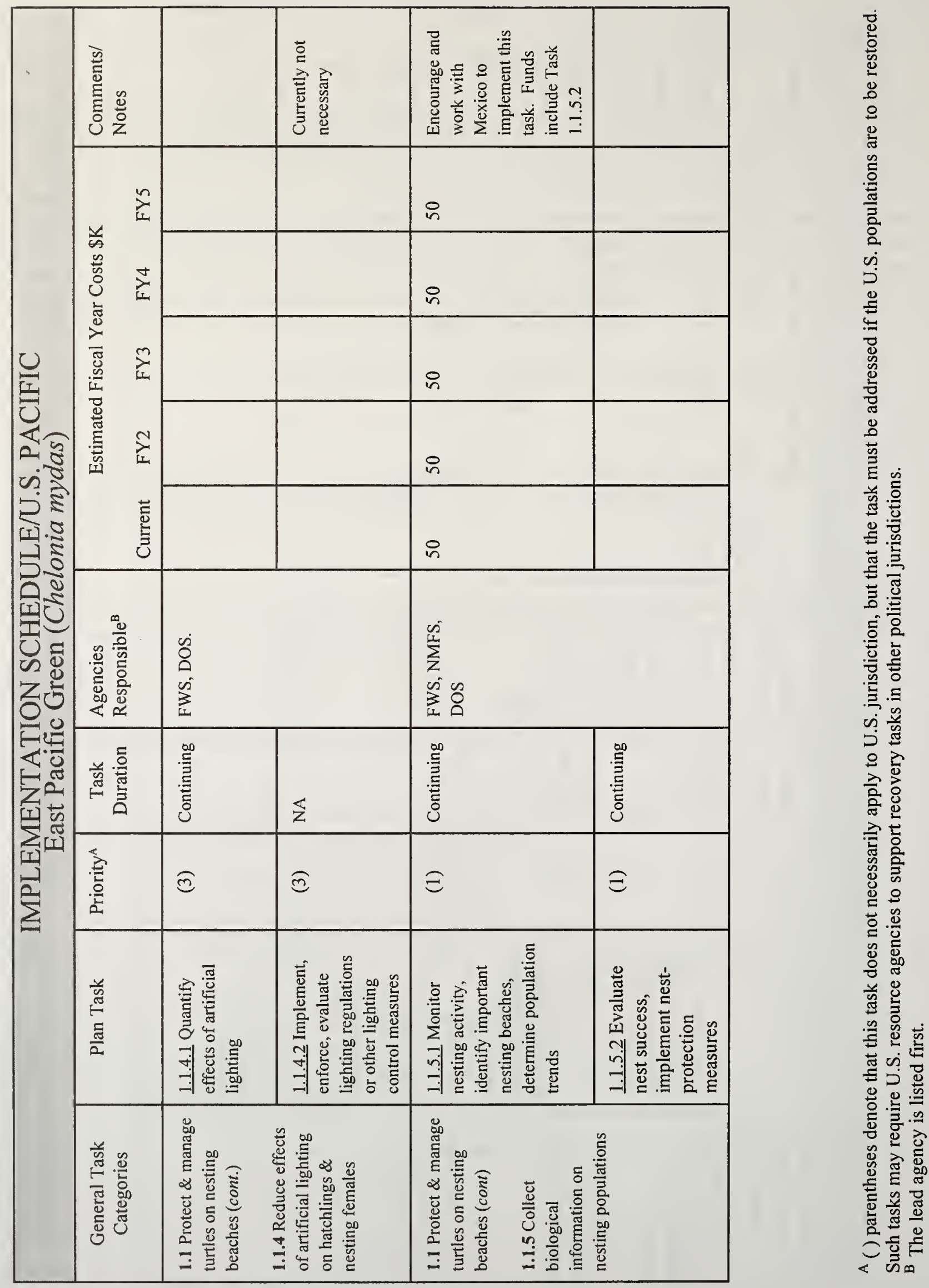


\begin{tabular}{|c|c|c|c|c|c|c|c|}
\hline \multirow{11}{*}{ 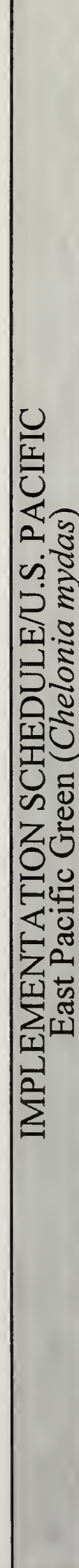 } & 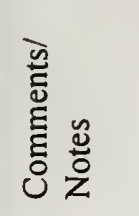 & 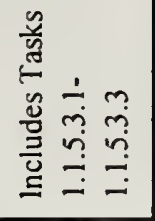 & & & & & \\
\hline & $\begin{array}{r}n \\
\times\end{array}$ & i & & & & & \\
\hline & 总 & i & & & & & \\
\hline & 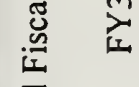 & i & & & & & \\
\hline & 壱 & i & & & & & \\
\hline & $\begin{array}{l}\bar{\Xi} \\
\bar{\Xi} \\
\bar{\Xi}\end{array}$ & $\stackrel{i}{0}$ & & & & & \\
\hline & 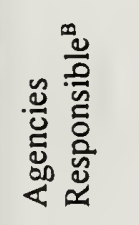 & 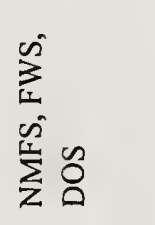 & & 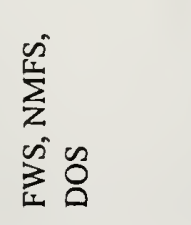 & $\begin{array}{l}\sum_{z}^{\infty} \\
\sum_{z}^{\infty} \\
\sum_{i=1}^{\infty}\end{array}$ & 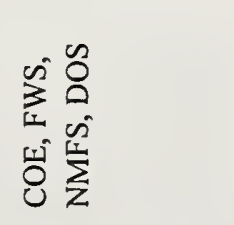 & \\
\hline & 总高 & $\begin{array}{l}\stackrel{n}{5} \\
\stackrel{5}{n} \\
n\end{array}$ & ڤ్ & 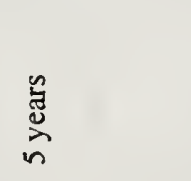 & 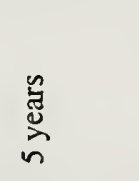 & 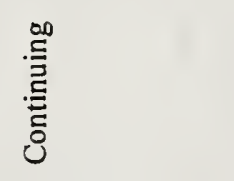 & 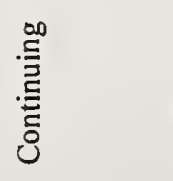 \\
\hline & 离 & - & $\Xi$ & - & - & న్ర & న్ \\
\hline & 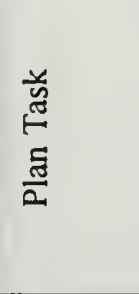 & 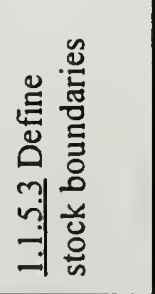 & 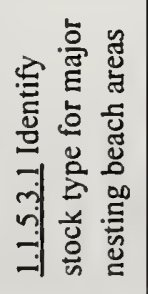 & 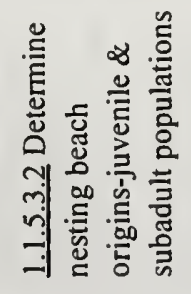 & 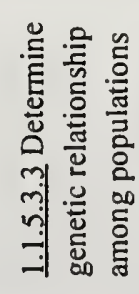 & 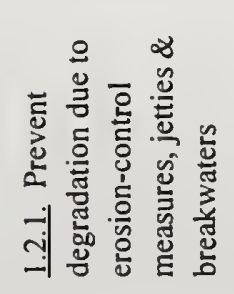 & 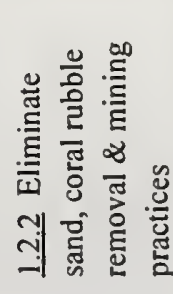 \\
\hline & 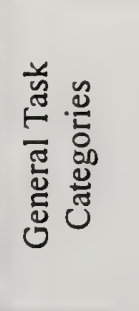 & 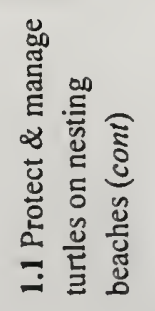 & 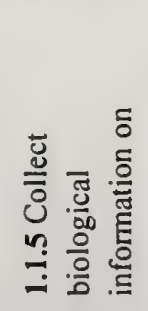 & 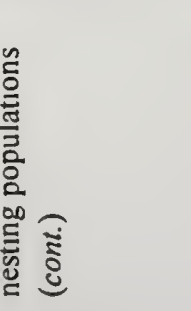 & & 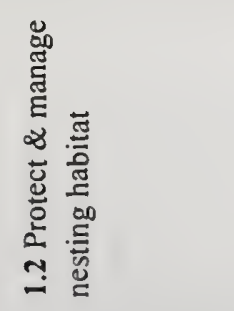 & \\
\hline
\end{tabular}

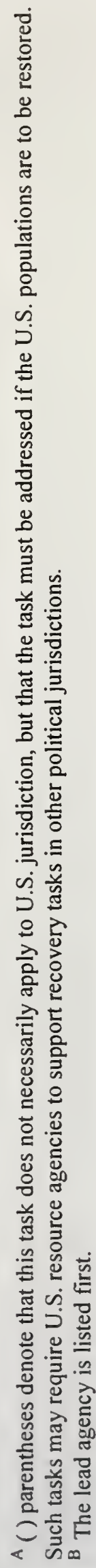




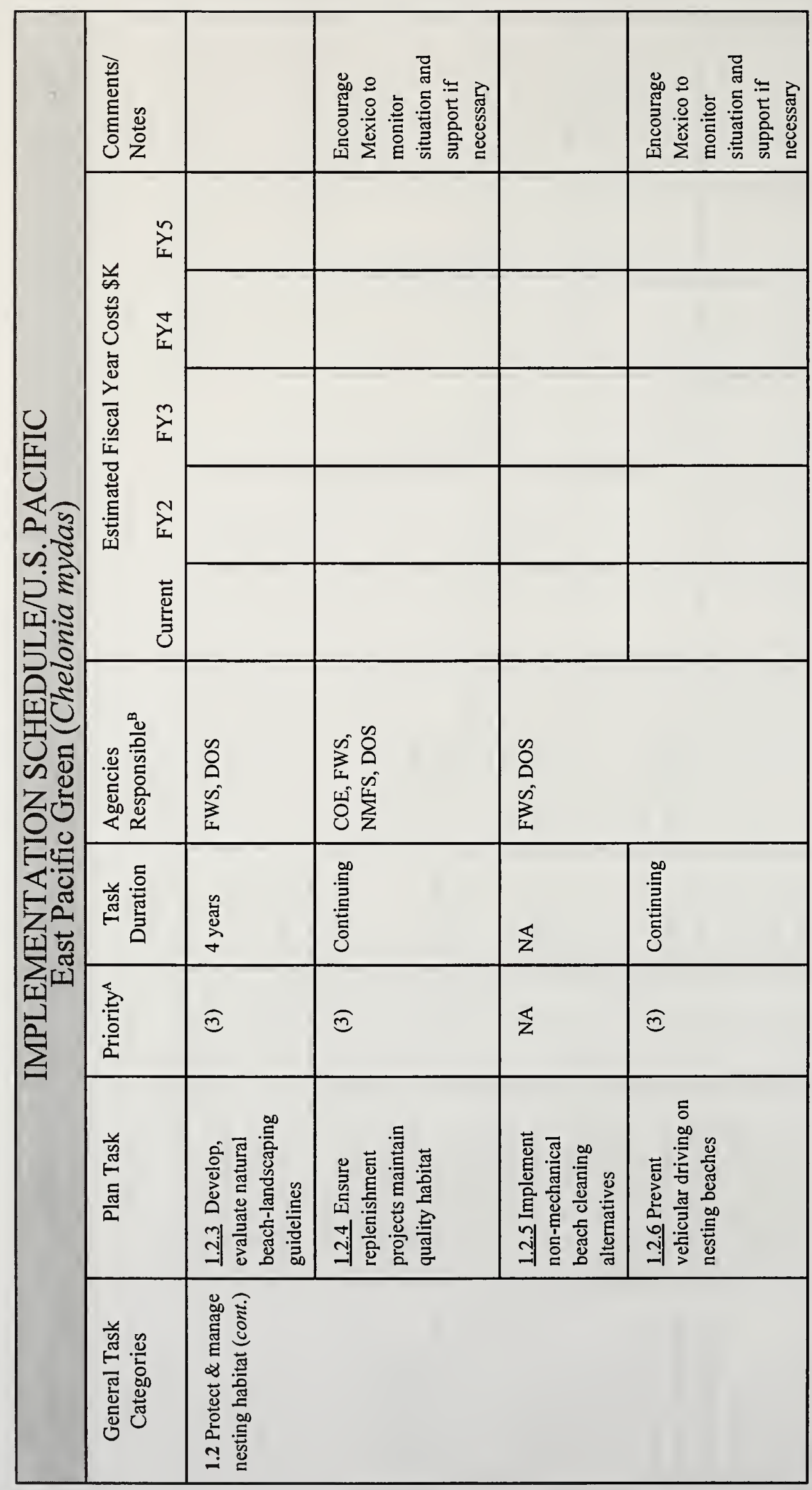

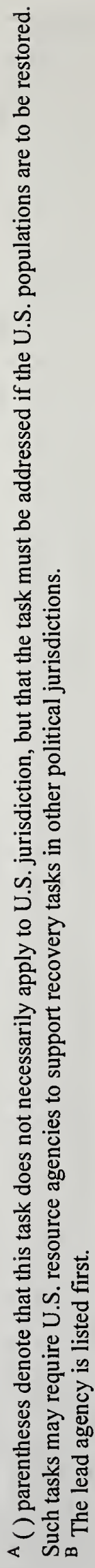



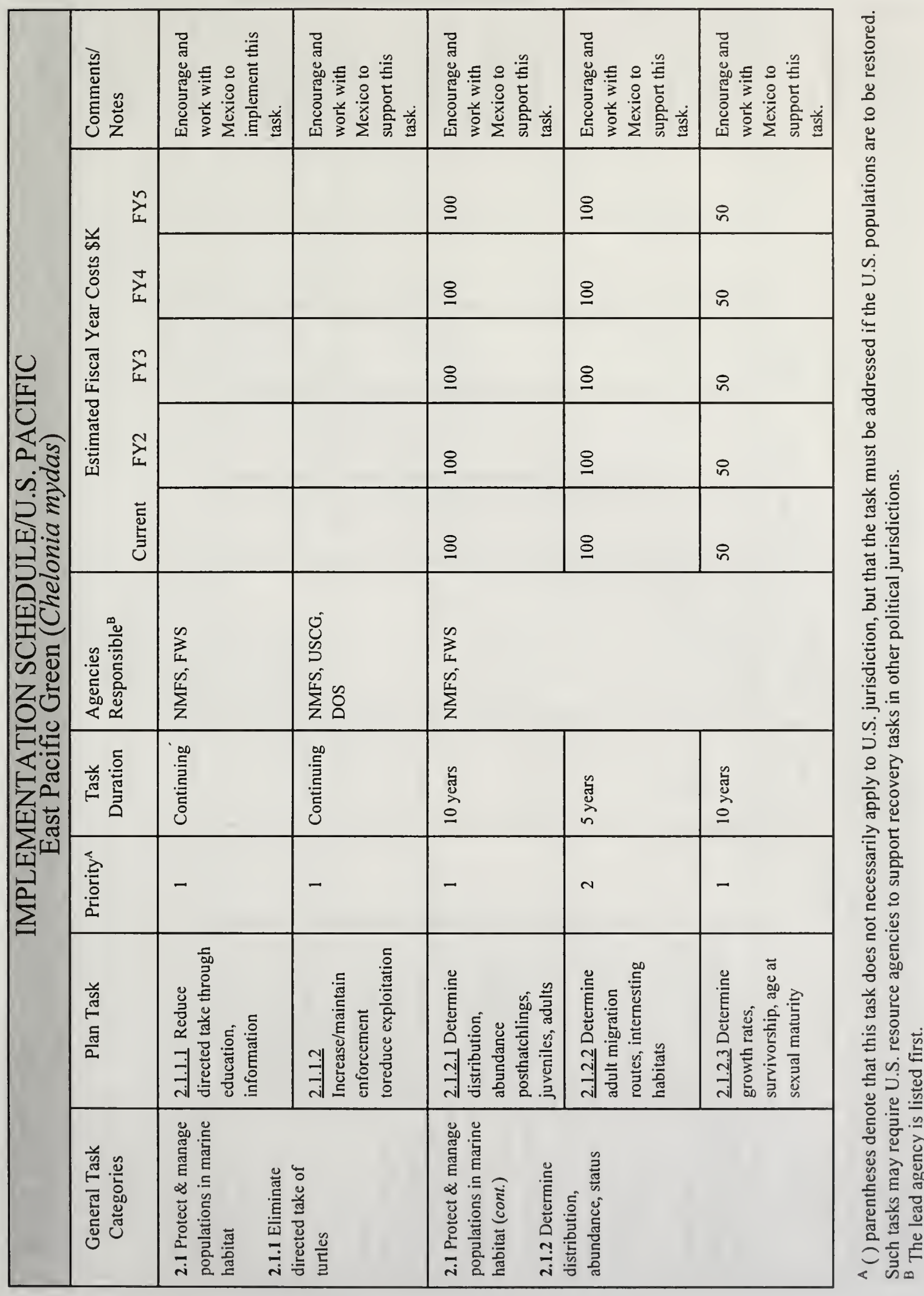

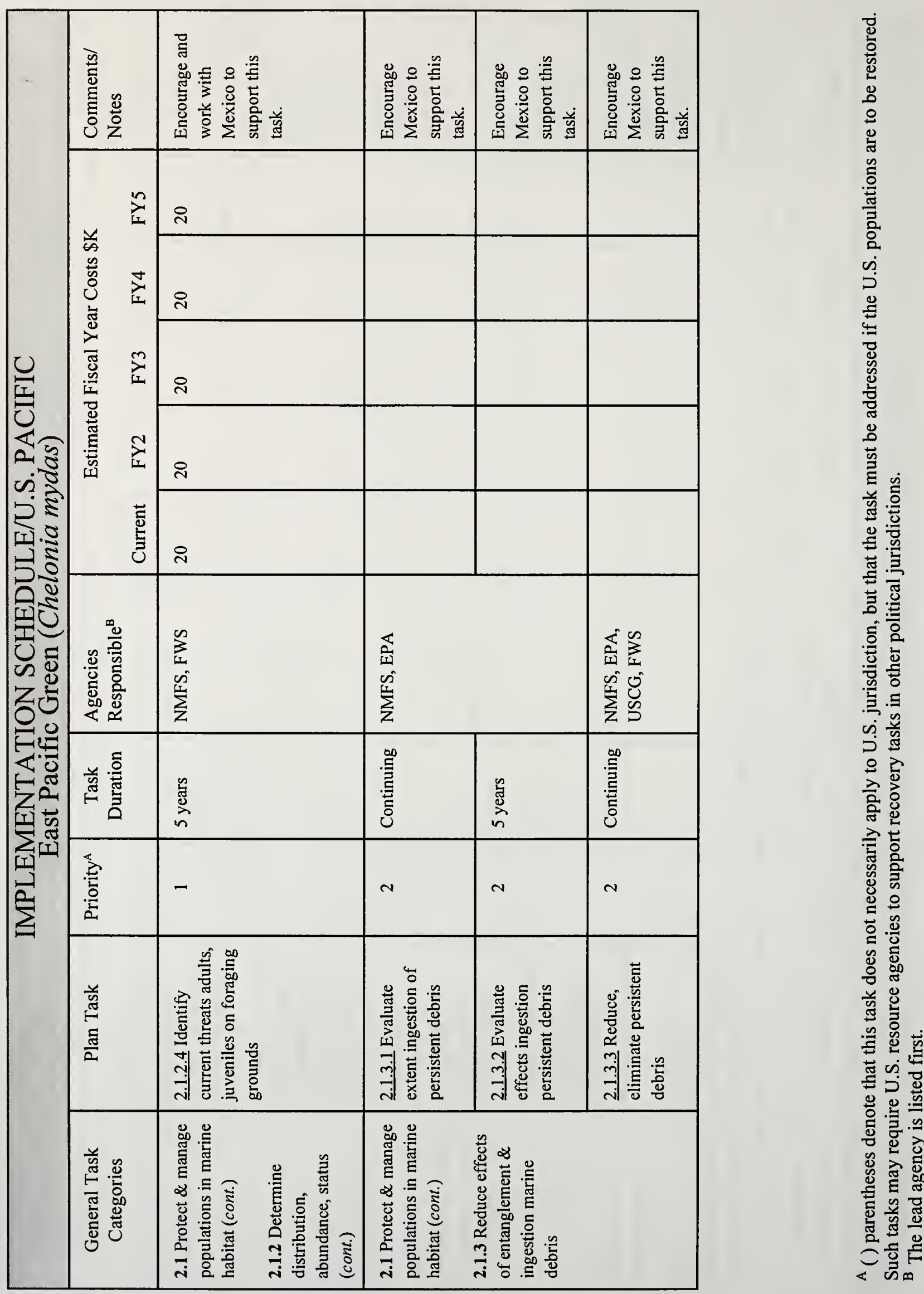

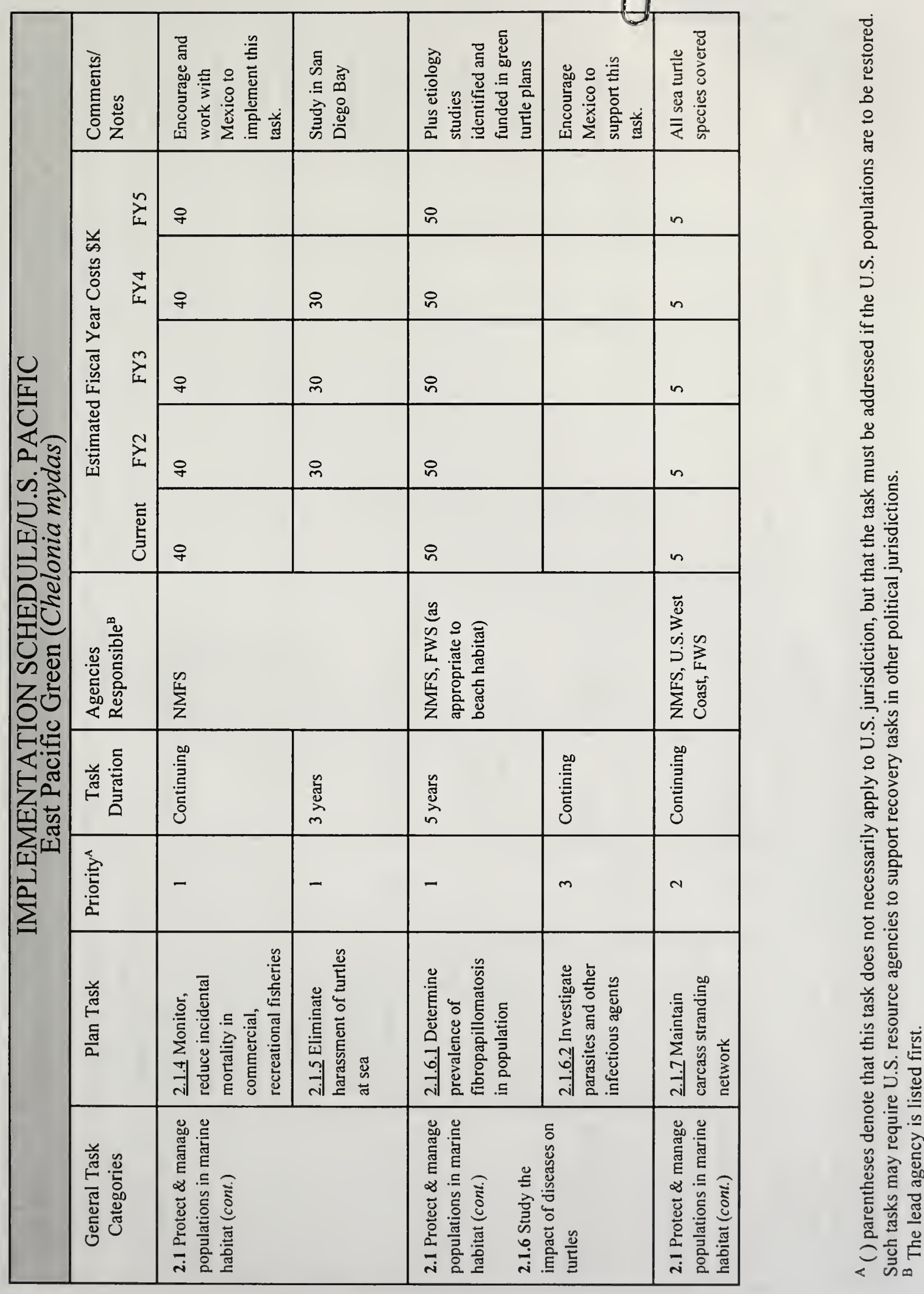


\begin{tabular}{|c|c|c|c|c|c|c|c|}
\hline ' & 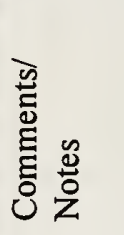 & 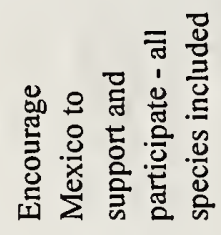 & 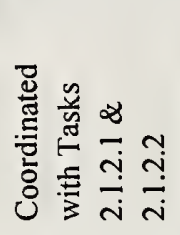 & 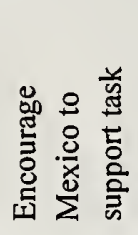 & 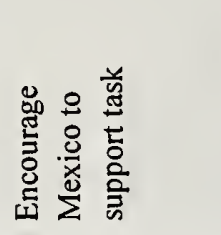 & 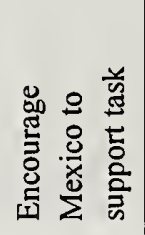 & 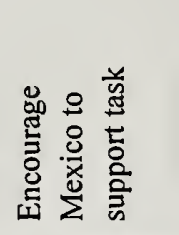 \\
\hline & $z_{I}^{n}$ & 8 & & & & & \\
\hline & $\int_{0}^{\infty}$ & 8 & & & & & \\
\hline & $\underset{\mathscr{C}}{\bar{Z}}$ & 8 & & & & & \\
\hline & 点 & 8 & & & & & \\
\hline 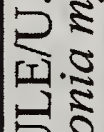 & 苛 & 8 & & & & & \\
\hline 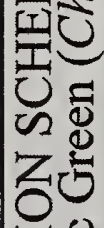 & 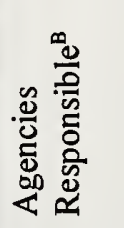 & 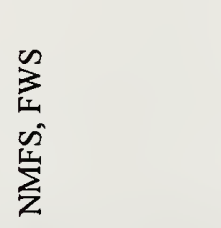 & $\sum_{z}^{\infty}$ & & 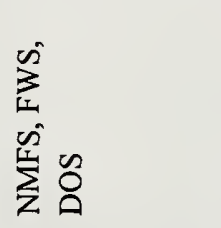 & 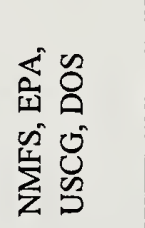 & 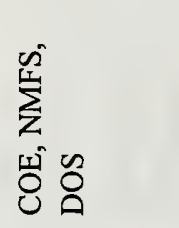 \\
\hline 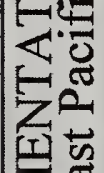 & 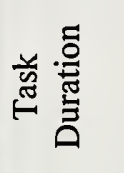 & . & 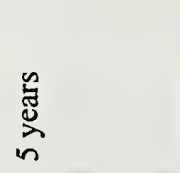 & . & . & .气 & 兽 \\
\hline 필 & 串 & $\sim$ & - & - & $\widehat{d}$ & $\widehat{d}$ & $m$ \\
\hline & $\begin{array}{l}\frac{y}{\tilde{\Xi}} \\
\stackrel{\Xi}{a} \\
\frac{\text { a }}{a}\end{array}$ & 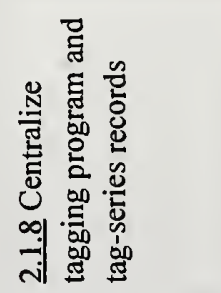 & 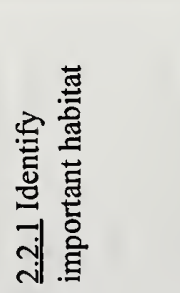 & 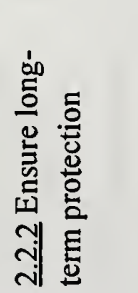 & 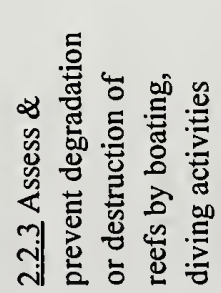 & 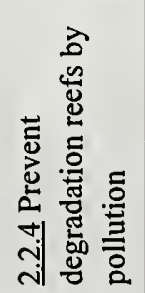 & 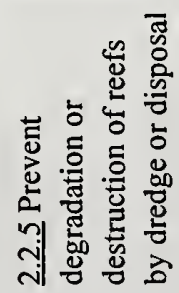 \\
\hline & 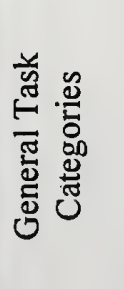 & 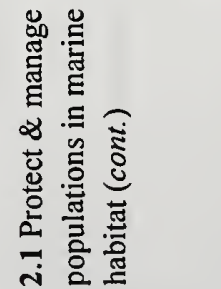 & 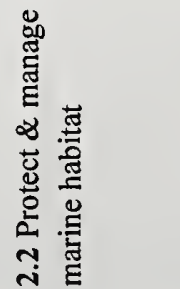 & & & & \\
\hline
\end{tabular}

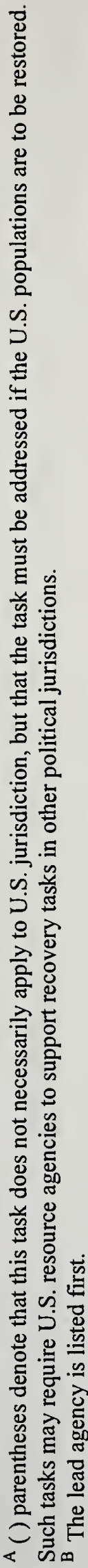



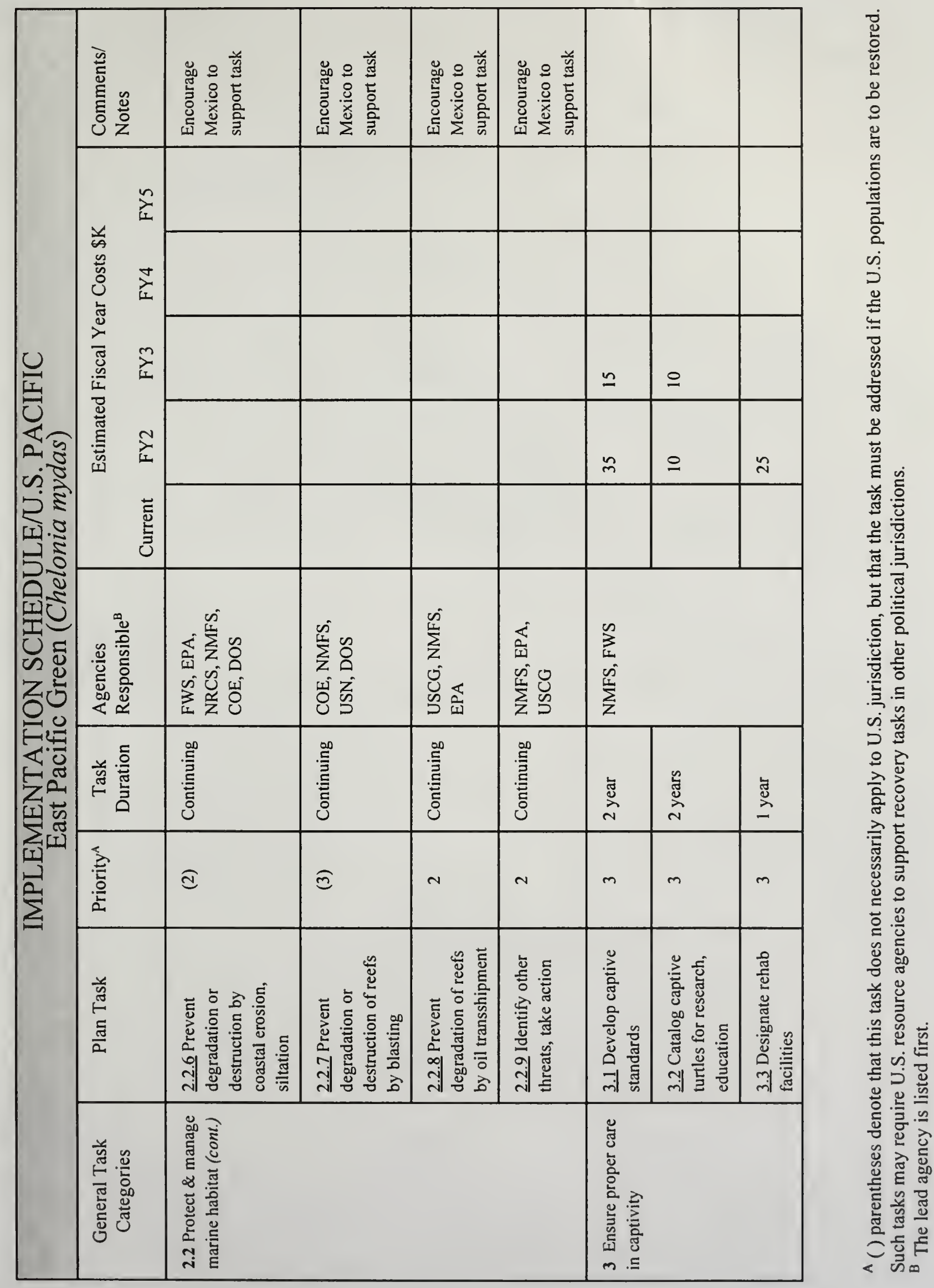


\begin{tabular}{|c|c|c|c|c|c|}
\hline+ & 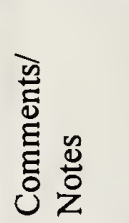 & & & & 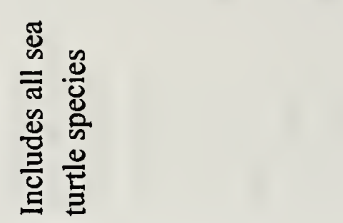 \\
\hline & & & & & \\
\hline & 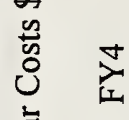 & & & & $\simeq$ \\
\hline & 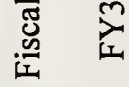 & & & & 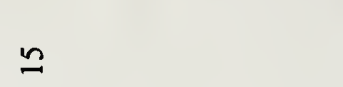 \\
\hline 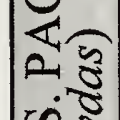 & $\begin{array}{l}\text { 莺 } \\
\text { 营 }\end{array}$ & & & & $\simeq$ \\
\hline 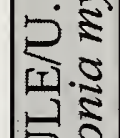 & 壳 & & & & $\underline{n}$ \\
\hline 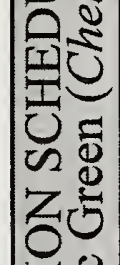 & 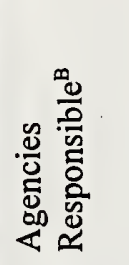 & 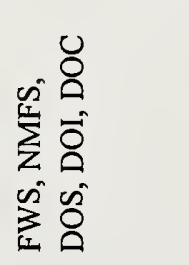 & & & 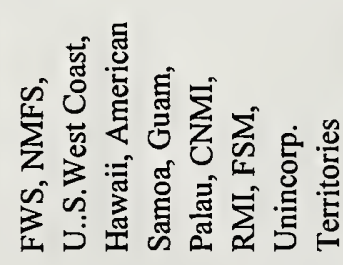 \\
\hline 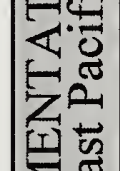 & 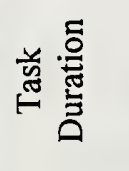 & 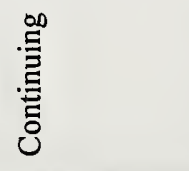 & 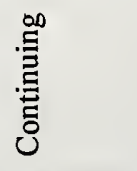 & 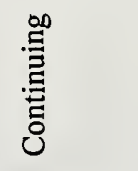 & 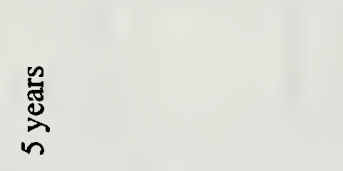 \\
\hline 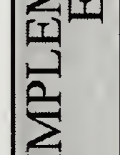 & 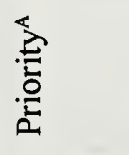 & - & - & - & $N$ \\
\hline & 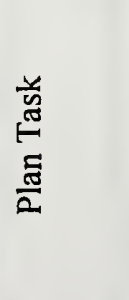 & 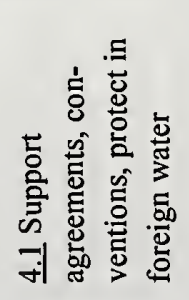 & 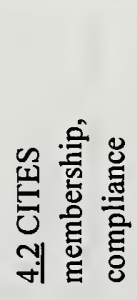 & 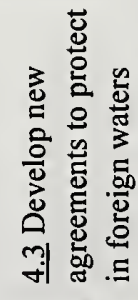 & 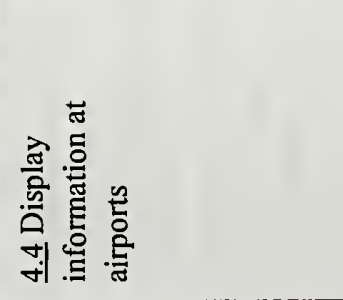 \\
\hline & 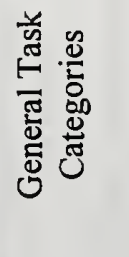 & 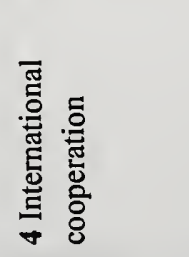 & & & \\
\hline
\end{tabular}

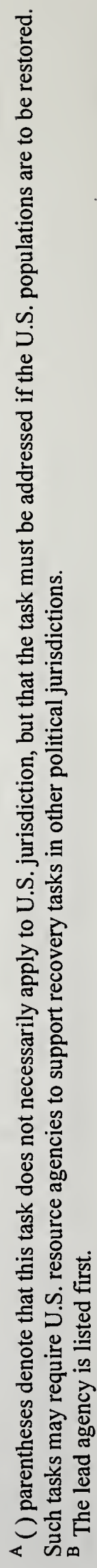



PENN STATE UNIVERSITY LIBRARIES

|| ||||||||||||||||||||

A000033084183 